U.S. Department of the Interior

U.S. Geological Survey

\title{
Documentation of Spreadsheets for the Analysis of Aquifer-Test and Slug-Test Data
}

Open-File Report 02-197

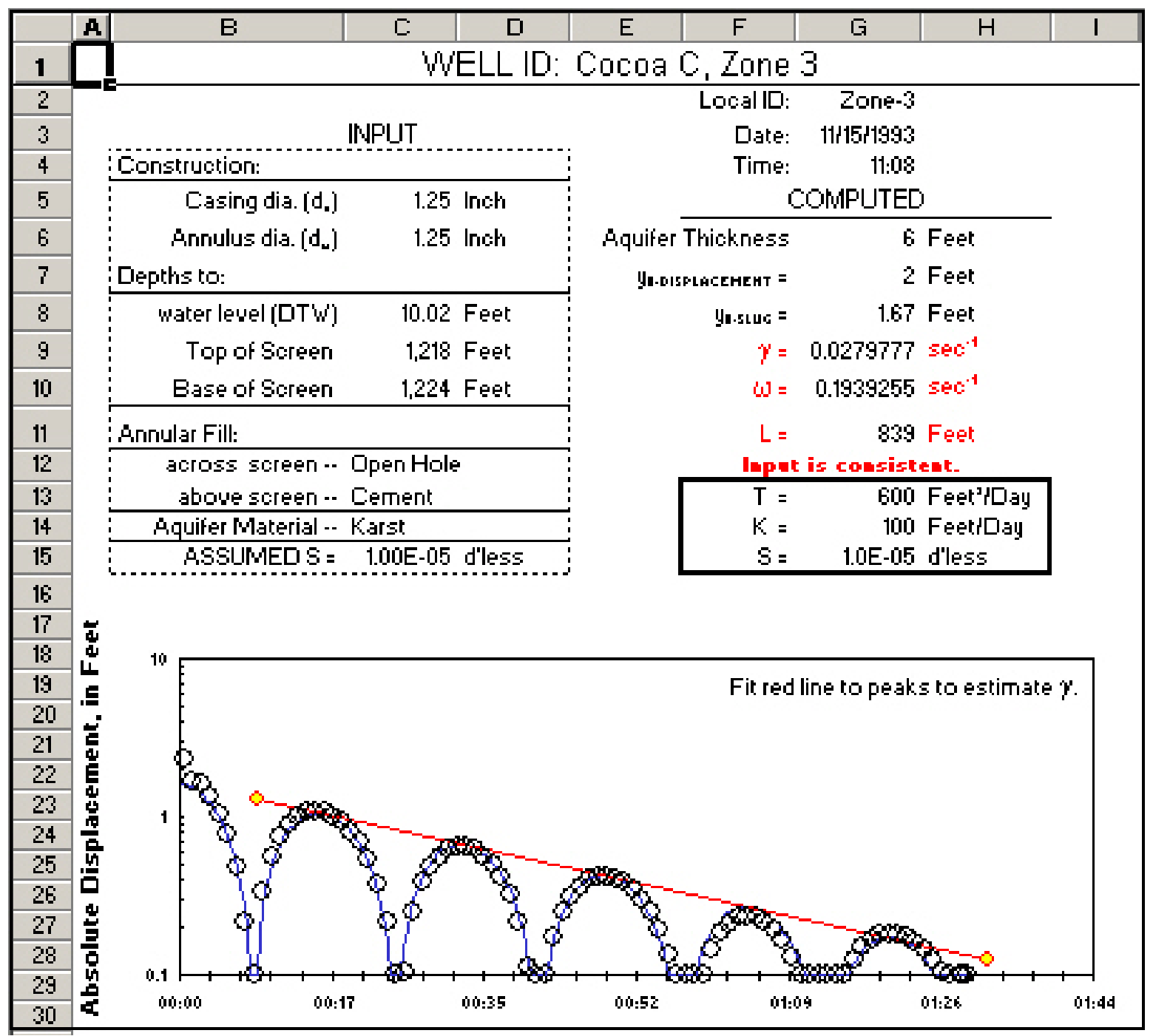




\section{Documentation of Spreadsheets for the Analysis of Aquifer-Test and Slug-Test Data}

By Keith J. Halford and Eve L. Kuniansky

U.S. GEOLOGICAL SURVEY

Open-File Report 02-197 


\title{
U.S. DEPARTMENT OF THE INTERIOR GALE A. NORTON, Secretary
}

\author{
U.S. GEOLOGICAL SURVEY
}

CHARLES G. GROAT, Director

Any use of trade, product, or firm names in this publication is for descriptive purposes only and does not imply endorsement by the U.S. Government

For additional information contact:

District Chief

U.S. Geological Survey

333 West Nye Lane, Room 203

Carson City, NV 89706-0866

email: GS-W-NVpublic-info@usgs.gov

http://nevada.usgs.gov
U.S. Geological Survey Information Services

Building 810

Box 25286, Federal Center

Denver, CO 80225-0286 


\title{
DOCUMENTATION OF SPREADSHEETS FOR THE ANALYSIS OF AQUIFER-TEST AND SLUG-TEST DATA
}

\author{
By Keith J. Halford and Eve L. Kuniansky
}

\section{Preface}

This report documents several spreadsheets that have been developed for the analysis of aquifer-test and slug-test data. Each spreadsheet incorporates analytical solution(s) of the partial differential equation for ground-water flow to a well for a specific type of condition or aquifer. The spreadsheets were written in Microsoft Excel version 9.0. Use of trade names does not constitute endorsement by the U.S. Geological Survey (USGS). The spreadsheets have been tested for accuracy using datasets from different aquifer tests or generated from the analytical solution. If users find or suspect errors with these spreadsheets, please contact the USGS.

Every effort has been made by the USGS or the United States Government to ensure the spreadsheets are error free. Despite our best efforts, the possibility exists that there are errors in the spreadsheets. The distribution of the spreadsheets does not constitute any warranty by the USGS, and no responsibility is assumed by the USGS in connection therewith. 
List of Symbols Used in This Report

$\mathrm{S}_{\mathrm{S}} \quad$ specific storage

compressibility of the aquifer skeleton

$\beta$

b'

$\Delta \mathbf{s}$

$\gamma$

g

h

He

$\mathrm{h}_{\mathrm{o}}$

dimensionless group that is similar to $u$,

Ho observed displacement

K

horizontal hydraulic conductivity

$\mathrm{K}_{\text {ANNULAR }}$

hydraulic conductivity of annular fill

$\mathrm{K}_{\mathrm{Z}} \quad$ vertical hydraulic conductivity of the confining unit

$\mathrm{K}_{\mathrm{Z}} / \mathrm{b}^{\prime} \quad$ leakance

n porosity

Q the pumping rate

$\mathbf{R} \quad$ radial distance from pumping well

$r_{E C} \quad$ effective casing radius

$r_{c} \quad$ casing radius

$\rho_{W} \quad$ density of water

$r_{w} \quad$ wellbore radius

s drawdown

s' residual drawdown

S aquifer storage coefficient

$S_{w} \quad$ total drawdown in pumping well

$S_{Y} \quad$ specific yield

T transmissivity

t time from the start of test

$t^{\prime} \quad$ time from the cessation of pumping

u dimensionless time

$\omega$ frequency of the oscillation

$W(u) \quad$ well function 
Contents

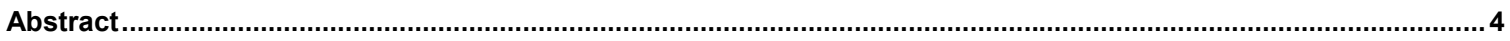

INTRODUCTION

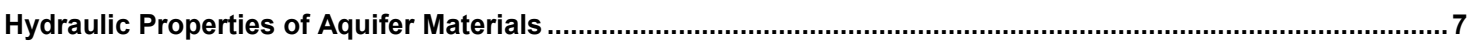

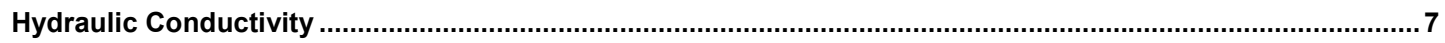

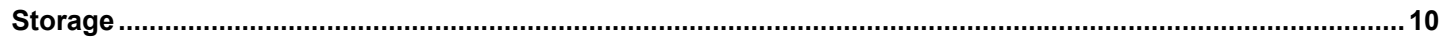

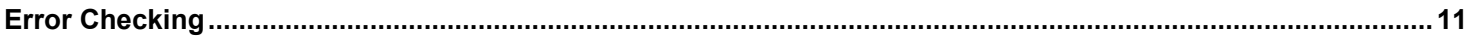

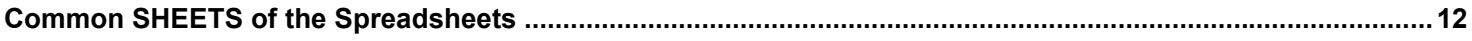

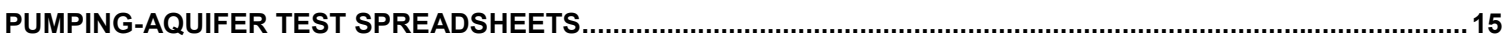

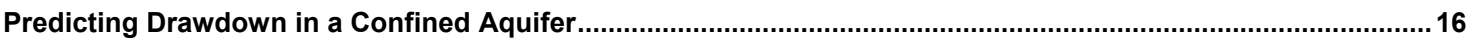

Instructions for Predicting Drawdown in a Confined Aquifer.................................................................17

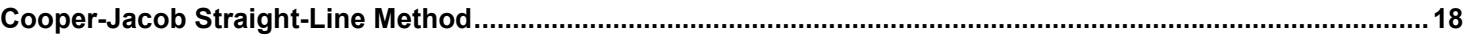

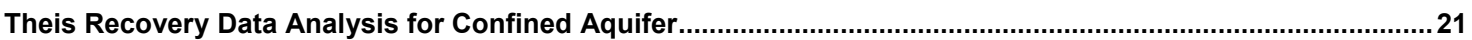

Jacob-Lohman Method for a Flowing Well in a Confined Aquifer ..................................................................22

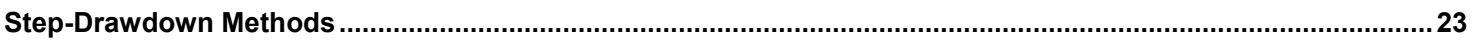

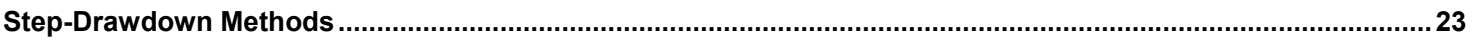

Instruction for Estimation of $T$ and $K$ from the Step Drawdown Spreadsheet..........................................27

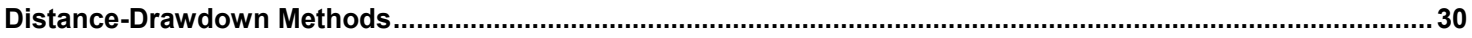

Instructions for Distance-Drawdown Spreadsheet ..................................................................................... 31

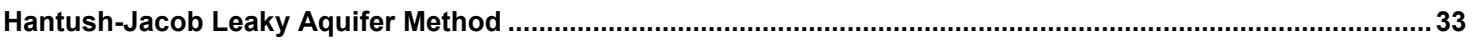

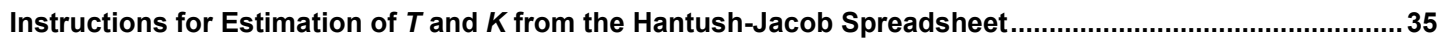

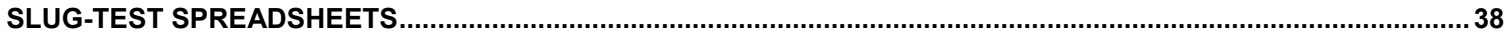

Instructions for Entering Data Into All of the Slug Test Spreadsheets .......................................................... 40

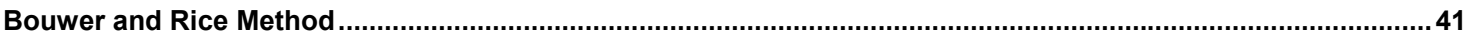

Instructions for Estimation of $K$ from the Bouwer and Rice Spreadsheet .................................................... 42

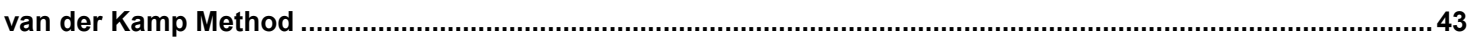

Instructions for Estimation of $\boldsymbol{T}$ from the van der Kamp Spreadsheet ........................................................... 44

Cooper, Bredehoeft, and Papadopulos Method as Modified by Greene and Shapiro ....................................47

Instructions for Estimation of $\boldsymbol{T}$ and $\boldsymbol{S}$ from the Cooper and others Spreadsheet ........................................48

REFERENCES 


\section{Abstract}

Several spreadsheets have been developed for the analysis of aquifer-test and slugtest data. Each spreadsheet incorporates analytical solution(s) of the partial differential equation for ground-water flow to a well for a specific type of condition or aquifer. The derivations of the analytical solutions were previously published. Thus, this report abbreviates the theoretical discussion, but includes practical information about each method and the important assumptions for the applications of each method. These spreadsheets were written in Microsoft Excel 9.0 (use of trade names does not constitute endorsement by the USGS).

Storage properties should not be estimated with many of the spreadsheets because most are for analyzing single-well tests. Estimation of storage properties from single-well tests is generally discouraged because single-well tests are affected by wellbore storage and by well construction. These non-ideal effects frequently cause estimates of storage to be erroneous by orders of magnitude. Additionally, single-well tests are not sensitive to aquiferstorage properties. Single-well tests include all slug tests (Bouwer and Rice Method, Cooper, Bredehoeft, Papadopulos Method, and van der Kamp Method), the Cooper-Jacob straight-line Method, Theis recovery-data analysis, Jacob-Lohman method for flowing wells in a confined aquifer, and the step-drawdown test.

Multi-well test spreadsheets included in this report are; Hantush-Jacob Leaky Aquifer Method and Distance-Drawdown Methods. The distance-drawdown method is an equilibrium or steady-state method, thus storage cannot be estimated. 


\section{INTRODUCTION}

Determination of the hydraulic properties of aquifers and confining units is critical to our understanding of ground-water flow and the development of ground-water flow models. The U.S. Geological Survey (USGS) is frequently asked to conduct and analyze aquifer tests.

Several spreadsheets were developed for the analysis of aquifer-test and slug-test data. Each spreadsheet incorporates analytical solution(s) of the partial differential equation for ground-water flow to a well for a specific type of condition or aquifer. The derivations of the analytical solutions were previously published. Thus, the report abbreviates theoretical discussions, but includes practical information, the important assumptions, and limitations for application of each method. These spreadsheets were written in Microsoft Excel version 9.0 (use of trade names does not constitute endorsement by the USGS).

Many excellent textbooks and USGS reports provide more thorough discussions of aquifer and slug tests and include more solutions than are provided here. Textbooks for formation-tests, aquifer-tests, and slug-tests analyses have been developed by; Lee (1982), Driscoll (1986), Dawson and Istok (1991), Kruseman and de Ridder (1994), Walton (1996), Hall and Chen (1996), Kasenow (1997), and Butler (1997). Some of the USGS compilations include, Ferris and others (1962), Benthall (1963), Stallman (1971), Lohman (1979), and Reed (1980). Lee (1982) is a text on well testing from the Petroleum Engineering field and is not commonly used by hydrogeologists. Driscoll (1986), "Groundwater and Wells" is an excellent reference covering all aspects of well design, drilling, and testing. A popular text for aquifer tests is by Kruseman and de Ridder (1994), which covers most types of tests in good detail. Butler (1997) developed one of the better textbooks for conducting and analyzing slug tests.

The USGS has published software for analysis of aquifer-test and slug-test data.

Barlow and Moench (1999) recently published the FORTRAN program WTAQ, which is based on radial axisymmetric flow to a well under confined or unconfined conditions. Sepulveda (1992) documented a FORTRAN program for analysis of underdamped and overdamped slug tests. Maslia and Randolph (1986) developed a FORTRAN program TENSOR2D for analysis of the transmissivity tensor for multi-well tests under anisotropic conditions. Greene and Shapiro (1998) developed a FORTRAN program for analysis of air pressurized slug tests. The capabilities of software by Sepulveda (1992) and Greene and Shapiro (1998) were duplicated in spreadsheets for more convenient analysis. The private sector has developed several comprehensive Graphic User Interface (GUI) packages for aquifer test analysis that include a wider suite of analysis methods than the set of spreadsheets described herein.

Before conducting an aquifer test or slug test, a reasonable estimate of the hydraulic properties at a site are needed to plan observation well spacing, select appropriate transducers and data loggers, determine appropriate pump size, and collect water-level data at appropriate time increments. Thus, the introduction includes a discussion of hydraulic properties of aquifer materials. The material presented is elementary for experienced hydrogeologists, but is included in this report, because these spreadsheets are in use by inexperienced hydrogeologists and hydrologic technicians.

A table of hydraulic-conductivity properties was developed and is used in the spreadsheets for logic checks that provide warning messages. These warning messages are useful for detecting data-entry errors. Aquifer storage properties are discussed in the report 
because a few spreadsheets require storage estimates. The hydraulic-properties information can also be used in the spreadsheet for calculating predicted drawdown of confined aquifers pumped at a constant rate.

The aquifer-test and slug-test analysis spreadsheets are similar in design. Similar pages in all of these spreadsheets are discussed in the introductory section. Instructions on the use of each spreadsheet are provided in a "stop format" presentation with text on the left and a graphic picture of the spreadsheet action on the right.

Many of the spreadsheets are for single-well tests. Estimation of storage properties from single-well tests is generally discouraged because single-well tests are affected by wellbore storage and by well construction. Additionally, this is discouraged because many of the single-well test analytical solutions are insensitive to the storage properties of the aquifer. Single-well tests include all slug tests (Bouwer and Rice Method, Cooper, Bredehoeft, Papadopulos Method, and van der Kamp Method), the Cooper-Jacob straight-line method, Theis recovery-data analysis, Jacob-Lohman method for flowing wells in a confined aquifer, and the step-drawdown test.

Multi-well test spreadsheets included in this report are; Hantush-Jacob Leaky Aquifer Method and Distance-Drawdown Methods. The distance-drawdown method is an equilibrium or steady-state method, thus no estimate of storage properties is possible from this method. 


\section{Hydraulic Properties of Aquifer Materials}

Aquifer-test or slug-test analyses may provide unrealistic estimates of hydraulic properties. The test results may be checked by comparing them to expected values for the tested material, a check made automatically by the spreadsheet analyses. These expected values were derived from a variety of sources, as described in the "Hydraulic Conductivity of Aquifer Materials, K" section. Additionally, a few of the spreadsheets require knowledge of aquifer-storage properties, described in the "Aquifer-Storage Properties, S" section. This section first provides introductory conceptual information about the hydraulic conductivity and storage coefficient values of common aquifer materials for inexperienced hydrogeologists and the "Error Checking" section discusses the error warnings in the spreadsheets associated with the estimate of hydraulic conductivity.

\section{Hydraulic Conductivity}

Aquifer properties for individual lithologies were derived from compilations of aquifer tests by the USGS and a variety of text books. Domenico and Schwartz (1990, pg. 65, Table 3.2 ), provide the broadest range of hydraulic conductivities $(K)$ for geologic materials. This broad range may be misleading because hydraulic conductivity tends to be log-normally distributed and the maximum and minimum ranges provided in some texts include values that, based on the authors experience, are unlikely to occur. Other texts, such as Bouwer (1978), provide order of magnitudes for typical ranges of geologic material. An informative discussion of porosity and permeability of natural materials was published by Davis (1969). Table 1 shows, what will be referred to as the extreme minimum and extreme maximum horizontalhydraulic conductivity along with the likely minimum and likely maximum values. Additionally, aquifer-test data that have been compiled for different major aquifers or areas is included in table 1.

Ranges of hydraulic conductivity for individual lithologies frequently are not useful constraints because many aquifers are a heterogeneous mixture of many lithologies. Ranges of hydraulic conductivity for aquifers that are comprised of unconsolidated sedimentary rocks were derived from three compilations of aquifer-test and slug-test results. Hydraulicconductivity data were compiled from 1,532 aquifer-test analyses and 5,071 specific-capacity data for the Gulf Coast Regional Aquifer-Systems Analysis (RASA) study, (Prudic, 1991). The sediments in the Gulf Coast RASA study area are unconsolidated gravels, sands, silts, and clays. Results of all of these tests are summarized in table 1.

Likely minimum and likely maximum estimates of hydraulic conductivity in alluvial sediments were assumed to be defined by the 25 -percentile and 75 -percentile values. The 25-75 percentile values ranged from 1-9 ft/day for the Surficial Aquifer-System in central Florida which is a fairly well-sorted mixture of fine sand and silt. Heterogeneous cross-bedded stream terrace deposits in, Fort Worth, Texas had a fairly wide range of likely hydraulicconductivity values, $1-100 \mathrm{ft} /$ day.

The sorting of unconsolidated sediments largely controls the expected range of hydraulic conductivity. A well-sorted sediment will have a much larger hydraulic conductivity than a poorly sorted sediment, because finer material fills the voids between coarser grains in poorly sorted sediment. The hydraulic conductivity of an unconsolidated sediment can be 
estimated empirically from the grain-size distribution (Vukovic and Soro, 1992). Hydraulic conductivity estimates from grain-size distributions typically have a greater uncertainty than estimates from aquifer tests.

The hydraulic conductivity of carbonate rock aquifers can range through many orders of magnitude, especially in karst terranes, where secondary porosity develops. Transmissivity estimates are typically reported for karst aquifers instead of hydraulic-conductivity estimates because the thicknesses of the contributing intervals are difficult to determine. The Upper Floridan aquifer, a karst aquifer in Florida, Georgia, and South Carolina, has transmissivities that typically range from 10,000 to $1,000,000 \mathrm{ft}^{2} /$ day (Miller, 1990, fig. 56). The Edwards aquifer, a karst aquifer in central Texas, has transmissivity values in the same range as the Upper Floridan, with some estimates as high as 20,000,000 $\mathrm{ft}^{2} /$ day (Maclay and Small, 1986; Hovorka and others, 1995). Transmissivity in karst generally occurs in small intervals of the total thickness. Where hydraulic-conductivity values were determined from the permeable zones of the total formation thickness, Reese and Cunningham (2000) estimated hydraulicconductivity values greater than $10,000 \mathrm{ft} /$ day.

Indurated sedimentary rocks and metamorphic rocks tend to have much lower hydraulic conductivities than unconsolidated sediments or carbonate rocks. For consolidated sedimentary rock and unconsolidated sediment with similar grain sizes, the rock will have a lower hydraulic conductivity because the rock is indurated. Metamorphic and crystalline rocks may be permeable when they are fractured or weathered.

Volcanic rocks, like carbonate rocks, have a wide range of hydraulic conductivity. The higher conductivity values occur in interflow zones between lava flows, which may behave like conduits. For the basalt aquifers of the Columbia Plateau in Washington and Oregon, hydraulic conductivity values typically range from 10 to 2,000 ft/day (Whitehead, R.L., 1994, fig. 75).

The hydraulic properties of confining units are not discussed although they can be important to some investigations. Neuzil (1994) has compiled hydraulic conductivity estimates for clays and shales from many investigations. The reported hydraulic conductivity values were estimated over length scales that ranged from inches to hundreds of miles. 
Table 1 Ranges of horizontal hydraulic conductivity of geologic material

[All values are feet per day]

\begin{tabular}{|c|c|c|c|c|}
\hline Aquifer Material & $\begin{array}{l}\text { Extreme } \\
\text { Minimum }\end{array}$ & $\begin{array}{l}\text { Likely } \\
\text { Minimum }\end{array}$ & $\begin{array}{l}\text { Likely } \\
\text { Maximum }\end{array}$ & $\begin{array}{l}\text { Extreme } \\
\text { Maximum }\end{array}$ \\
\hline \multicolumn{5}{|l|}{ Unconsolidated Sedimentary Rock } \\
\hline Gravel $^{1,5}$ & 90 & 300 & 3000 & 3000 \\
\hline Sand and Gravel Mixes ${ }^{1}$ & 1 & 30 & 300 & 300 \\
\hline Coarse Sand ${ }^{1}$ & 50 & 70 & 300 & 300 \\
\hline Medium Sand ${ }^{1,5}$ & 1 & 20 & 70 & 200 \\
\hline Fine Sand ${ }^{1,5}$ & 0.05 & 3 & 20 & 20 \\
\hline Gulf Coast Aquifer Systems (6603 values) ${ }^{2}$ & 2 & 30 & 200 & 800 \\
\hline Stream Terrace Deposit, Fort Worth, Texas (59 values) ${ }^{3}$ & 0.01 & 1 & 100 & 300 \\
\hline Surficial Aquifer, central Florida (fine sand and silt values) ${ }^{4}$ & 0.01 & 0.1 & 30 & 50 \\
\hline Silt, Loess ${ }^{5}$ & 0.0003 & 0.001 & 0.1 & 6 \\
\hline Till $^{1,5}$ & 0.0000003 & 0.003 & 0.3 & 0.6 \\
\hline Clay soils (surface) ${ }^{1}$ & 0.01 & 0.01 & 1 & 1 \\
\hline Clay $^{5,7}$ & 1.00E-06 & 1.00E-05 & $1.00 \mathrm{E}-04$ & 1.00E-03 \\
\hline \multicolumn{5}{|l|}{ Carbonate Rocks } \\
\hline Unweathered Marine Clay ${ }^{5}$ & 2.00E-07 & 2.00E-07 & 0.0006 & 0.0006 \\
\hline Karst ${ }^{4,5,8}$ & 0.3 & 10 & 1,000 & 10,000 \\
\hline Reef Limestone ${ }^{5}$ & 0.3 & 10 & 1,000 & 6,000 \\
\hline Limestone, Dolomite ${ }^{5}$ & 0.0003 & 0.004 & 0.1 & 2 \\
\hline \multicolumn{5}{|l|}{ Indurated Sedimentary Rock } \\
\hline Medium-Grained Sandstone ${ }^{6,9}$ & 0.001 & 1 & 10 & 80 \\
\hline Fine-Grained Sandstone ${ }^{1,6}$ & 0.0001 & 0.001 & 1 & 6 \\
\hline Siltstone ${ }^{6}$ & 0.000001 & 0.00001 & 0.005 & 0.04 \\
\hline Claystone $^{6,7,10}$ & $3.00 \mathrm{E}-09$ & $1.00 \mathrm{E}-06$ & $1.00 \mathrm{E}-05$ & 3.00E-05 \\
\hline Shale $^{7}$ & $1.00 \mathrm{E}-08$ & $1.00 \mathrm{E}-07$ & $1.00 \mathrm{E}-04$ & 1 \\
\hline Anhydrite ${ }^{5}$ & $1.00 \mathrm{E}-07$ & $1.00 \mathrm{E}-07$ & 0.006 & 0.006 \\
\hline \multicolumn{5}{|l|}{ Metamorphic or Volcanic Rock } \\
\hline Permeable Basalt ${ }^{5}$ & 0.1 & 1 & 100 & 6000 \\
\hline Basalt $^{5}$ & 0 & 0.03 & 0.1 & 0.1 \\
\hline Fractured Igneous and Metamorphic Rock ${ }^{1}$ & 0.001 & 0.05 & 10 & 100 \\
\hline Unfractured Igneous and Metamorphic Rock ${ }^{1,5}$ & 0 & 1E-8 & 0.00006 & 0.00006 \\
\hline Weathered Granite ${ }^{6}$ & 0.1 & 1 & 10 & 20 \\
\hline Weathered Gabbro ${ }^{6}$ & 0.1 & 0.1 & 1 & 1 \\
\hline
\end{tabular}

1 Bouwer, 1978 (order of magnitude in meter/day)

2 Prudic, 1991

3 Sonia A. Jones, USGS, Written commun., 1998

4 Slug Test Results 1998-2001, Orlando Subdistrict, USGS

5 Domenico and Schwartz, 1990

6 Morris and Johnson, 1967

7 Wolff, 1982

8 Reese and Cunningham, 2000

9 Kuniansky and Hamrick, 1998

10 Neuzil, 1994 


\section{Storage}

The storage coefficient ( $\boldsymbol{S}$ ) can be defined as the volume of water that an aquifer releases or uptakes per unit surface area of aquifer per unit change of head. The storage coefficient of an unconfined aquifer is approximately equal to the specific yield $\left(\boldsymbol{S}_{Y}\right)$ which is generally related to the amount of water that can be released by gravity drainage. In confined aquifers, the storage coefficient is related to the compressibility of the aquifer and fluid and the thickness of the aquifer. Storage coefficients for confined aquifers generally range from 0.00001 to 0.001 (Bouwer, 1978, Fetter, 1994).

Specific storage $\left(\boldsymbol{S}_{\boldsymbol{S}}\right)$ is related to the storage coefficient by $\boldsymbol{S}=\boldsymbol{S}_{\boldsymbol{S}} \boldsymbol{b}$, where $\boldsymbol{S}_{\boldsymbol{S}}$ is the volume of water an aquifer releases or uptakes per unit volume of an aquifer per unit change of head. Specific storage is also known as the elastic storage coefficient and is defined by$$
S_{s}=\rho_{w} g(\varepsilon+n \beta)
$$

where,

$\rho_{w}$ is the density of water,

$g$ is the constant for the acceleration of gravity,

$\varepsilon \quad$ is the compressibility of the aquifer skeleton,

$\boldsymbol{n}$ is porosity, and

$\beta \quad$ is the compressibility of water.

Specific storage has units of $1 / \mathrm{L}$ and is generally greater than $10^{-6} \mathrm{ft}^{-1}$ and less than $10^{-5} \mathrm{ft}^{-1}$.

For unconfined aquifers, the specific yield is the amount of water that can be drained by gravity or moved into voids displacing air. The storage coefficient for an unconfined aquifer is given by the equation:

$$
S=S_{Y}+h S_{S} \cong S_{Y}
$$

where $\boldsymbol{h}$ is the saturated thickness of the unconfined aquifer.

The storage coefficient for unconfined sediments is approximately equal to the $\boldsymbol{S}_{Y}$, because $\boldsymbol{S}_{\boldsymbol{Y}}$ is generally several orders of magnitude greater than $\boldsymbol{h} \boldsymbol{S}_{\boldsymbol{S}}$. Values for specific yield for unconfined unconsolidated sediments are provided in table 2 . 
Table 2 Ranges of specific yield of unconfined aquifers composed of unconsolidated sediments

\begin{tabular}{llll}
\hline Material & Maximum & Minimum & Average \\
\hline Clay & 0.05 & 0. & 0.02 \\
Sandy Clay & 0.12 & 0.03 & 0.07 \\
Silt & 0.19 & 0.03 & 0.18 \\
Fine Sand & 0.28 & 0.10 & 0.21 \\
Medium Sand & 0.32 & 0.15 & 0.26 \\
Coarse Sand & 0.35 & 0.20 & 0.27 \\
Gravelly Sand & 0.35 & 0.20 & 0.25 \\
Fine Gravel & 0.35 & 0.21 & 0.25 \\
Medium Gravel & 0.26 & 0.13 & 0.23 \\
Coarse Gravel & 0.26 & 0.12 & 0.22 \\
\hline
\end{tabular}

Source: Johnson, 1967

\section{Error Checking}

A minimal level of error checking is implemented in all of the spreadsheets. Internal inconsistencies in data entry or physically implausible results cause an error message to be reported instead of an estimate of $\boldsymbol{K}$. Incorrectly specifying units of input data is the most common error that users have made. Errors that cause estimates of $\boldsymbol{K}$ to not be reported are summarized in table 3 .

Table 3 Errors that cause $\mathrm{K}$ to not be estimated.

\section{Water level is below base of screen}

Casing diameter is greater than the annular diameter

Base of screen is deeper than base of aquifer

Screen length is less than $0.1 \mathrm{ft}$

Slope will produce a negative $\boldsymbol{K}$

$\boldsymbol{K}$ estimate is less than extreme minimum $\boldsymbol{K}$ for selected aquifer material

$\boldsymbol{K}$ estimate is greater than extreme maximum $\boldsymbol{K}$ for selected aquifer material

Discrepancy between observed and expected slug displacement is greater than maximum $20 \%$ 
The thresholds for subjectively defined errors, such as the range of hydraulic conductivity associated with an aquifer material, are intended to be modified by the user. The hydraulic properties that are listed in table 1 are the default specifications in all of the spreadsheets. These ranges can be modified easily and additional materials can be included in the table. The discrepancy between observed and expected slug displacement is another subjective error that can be changed from the default threshold of 20 percent.

The default ranges of hydraulic conductivity for each material are broad and should be refined with hydraulic conductivity data that is specific to an investigator's study area. Compilations of aquifer-test data have been prepared in many offices of the USGS and could serve as a source of local information. Some offices have published these in reports, such as Slack and Darden (1991), Aucott and Newcome (1986), and Newcome (1993). If the aquifer material in your area is not listed, pick the closest associated material, such as clay instead of saprolite. Ignore the warning message if data entry is correct and consider revising the aquifer properties table.

\section{Common SHEETS of the Spreadsheets}

All of the spreadsheets for analyzing test data have four standard "SHEETS" (a tabbed page within the spreadsheet program) that are labeled: (1) COMPUTATION, (2) DEFAULT PROPERTIES and SETTINGS, (3) OUTPUT, and (4) DATA (fig. 1). The COMPUTATION sheet is where computations are made from data inserted into cells of the OUTPUT and DATA sheets. Users should not change any cells of the spreadsheet on the COMPUTATION sheet. The DEFAULT PROPERTIES and SETTINGS sheet contains information that the user may want to modify, such as significant digits. The significant digit default is 1 , which is recommended for reporting aquifer test results by the authors. The DEFAULT PROPERTIES and SETTINGS sheet lists hydraulic conductivities of geologic materials from table 1 . The list should be modified to include more specific information about local aquifers in a study area. The OUTPUT sheet creates a summary report of a test that includes required information for an aquifer test analysis. Thus, information is entered into cells labeled "INPUT" on the "OUTPUT" sheet, such as, well construction, aquifer thickness, aquifer material, site ID, and remarks about the test. Additional information such as a well construction diagram and pictures of the site also could be pasted on the "OUTPUT" sheet. The DATA sheet of the spreadsheet is for the data logger information or drawdown measurements. Slug tests require additional information about the method of creating the displacement and slug dimensions. Additional information for slug tests is entered into cells of the DATA sheet. 


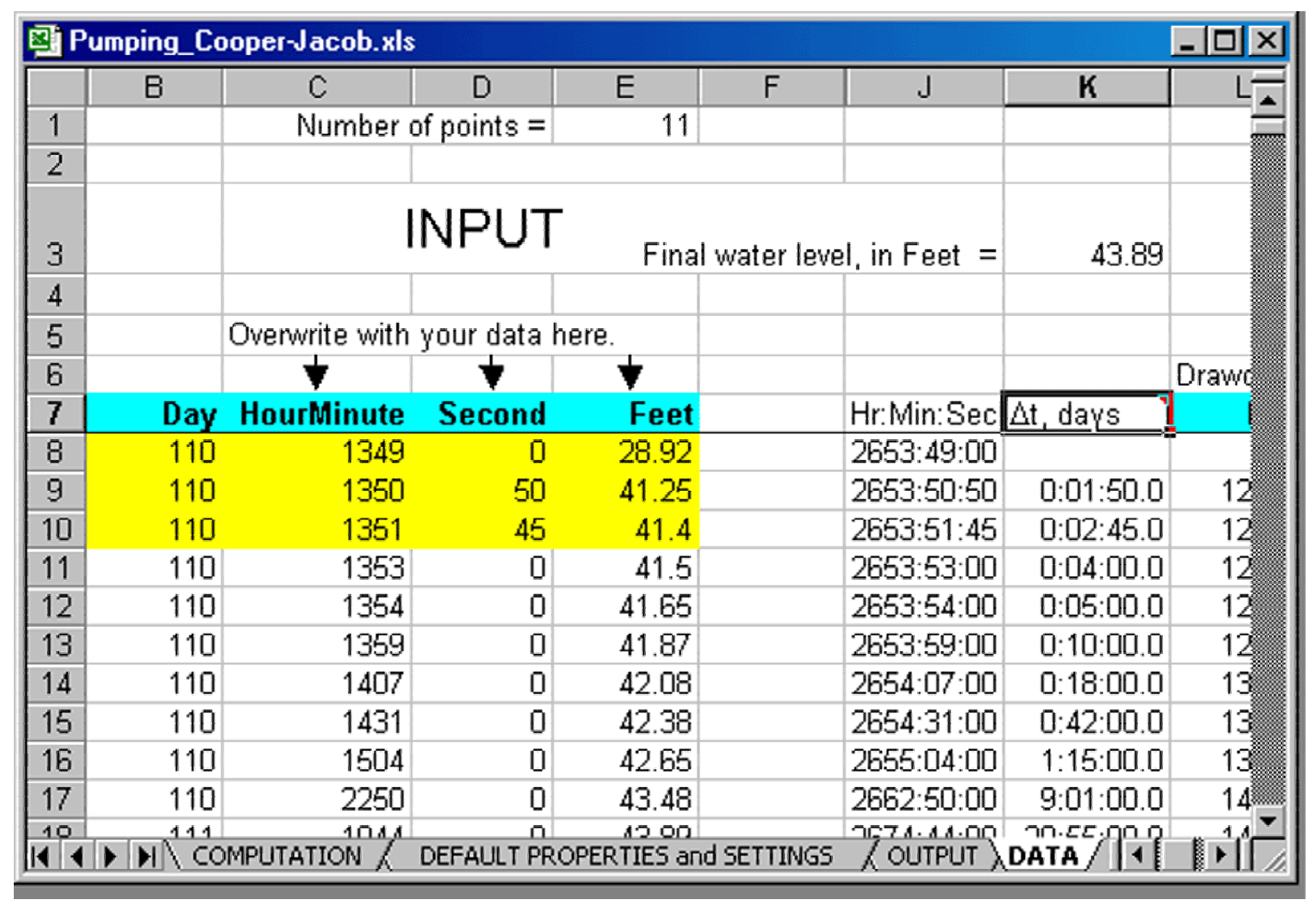

Figure 1 View of the four pages common to most spreadsheets (DATA page of the Cooper-Jacob Straight-line Method spreadsheet is revealed).

The Step-Drawdown spreadsheet differs from the above format in that it replaces the DATA page with the following 2 pages, WATER-LEVEL DATA and FLOW RATES (fig. 2). In figure 3, the Hantush-Jacob Leaky Aquifer spreadsheet replaces the DATA page with a page for the data from each individual well.

Once the user gets used to using one of the spreadsheets, it will be easy to understand how to use the spreadsheets for other methods. 


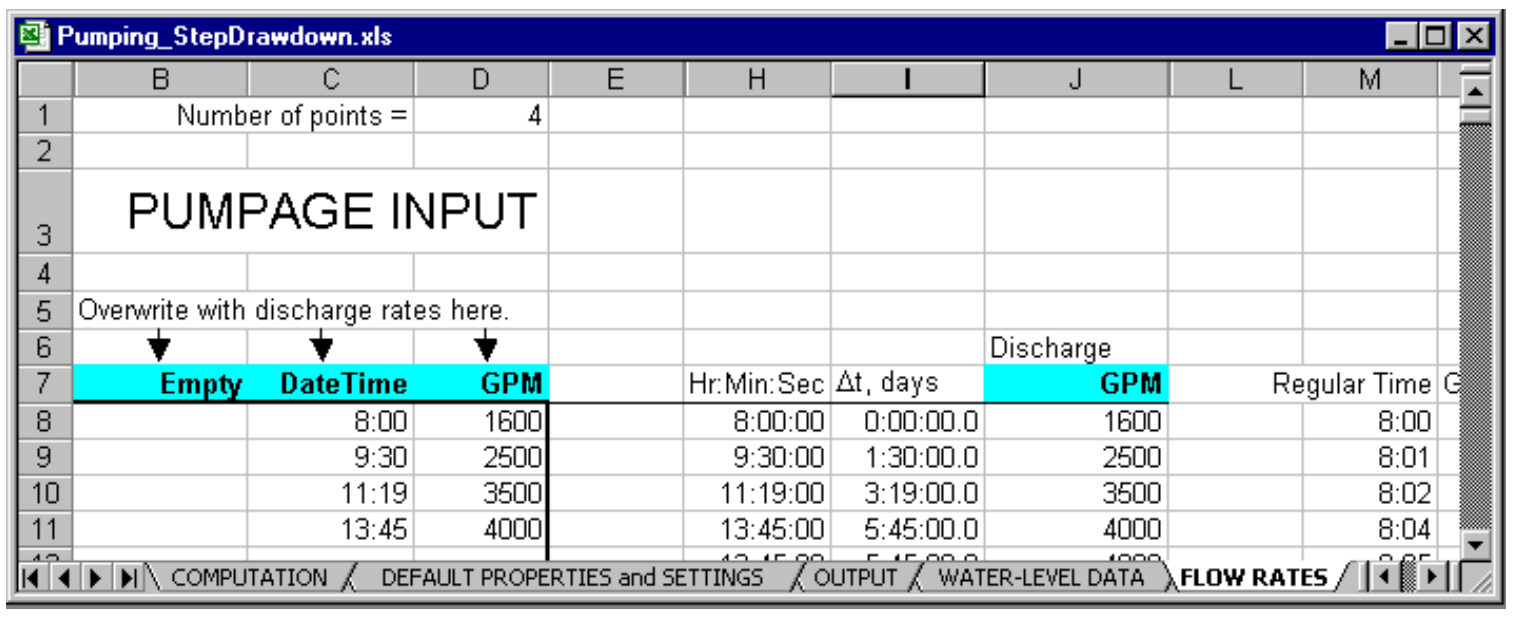

Figure 2 View of the five pages for the Step-Drawdown spreadsheet (FLOW RATES page is revealed).

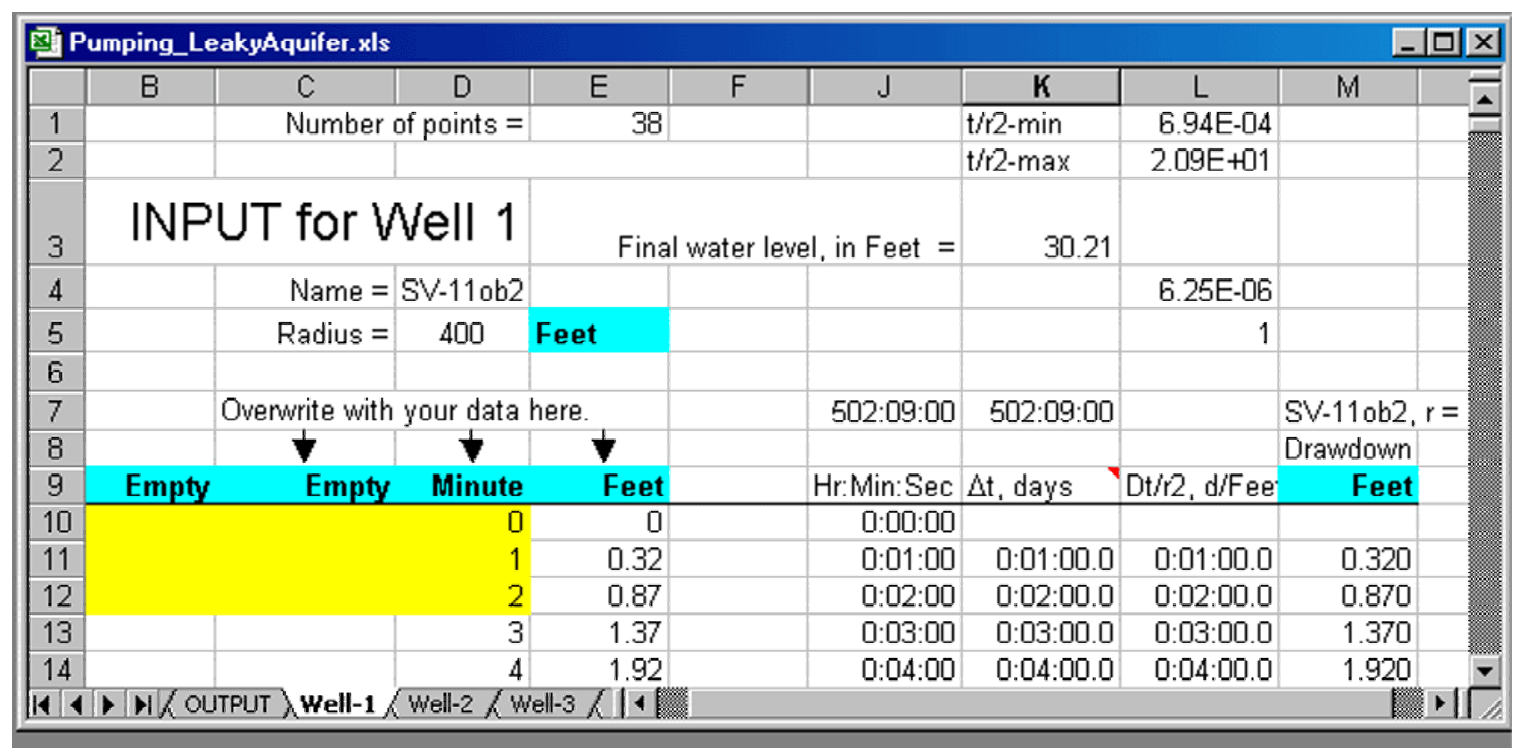

Figure 3 View of the seven pages for the Hantush-Jacob Leaky Aquifer spreadsheet (Well-1 page is revealed). 


\section{PUMPING-AQUIFER TEST SPREADSHEETS}

The aquifer-test spreadsheets are based on drawdown response to a pumping well or a flowing well. A pumping-aquifer test imposes a greater stress of longer duration than does a slug test, and thus provides estimates of hydraulic properties of a larger region around the well than does a slug test. In general, the transmissivity $(\boldsymbol{T})$ is estimated and the horizontal hydraulic conductivity $(\boldsymbol{K})$ is computed by dividing $\boldsymbol{T}$ by aquifer thickness. The spreadsheets are designed for constant discharge tests, except for the step-drawdown test and flowing-well test.

One spreadsheet is designed for planning aquifer tests and predicts drawdowns from constant-rate pumping in a confined aquifer. The analytical solution is for radial axisymmetric flow to a fully penetrating well (Theis, 1935). Predicted drawdowns are useful for estimating pressure ranges of transducers, pump capacity, and well spacing. The style of the predictive spreadsheet differs from the aquifer-test analysis spreadsheets.

Transmissivity is the primary aquifer property that can be estimated with all of the spreadsheets. Cooper-Jacob straight-line and distance-drawdown method spreadsheets are for estimating $\boldsymbol{T}$ exclusively. Well losses to the production well also can be estimated with the stepdrawdown spreadsheet. The hydraulic conductivity of an adjacent confining unit $\left(\boldsymbol{K}_{\mathbf{z}}\right)$ and aquifer storage $(\boldsymbol{S})$ can be estimated with the Hantush-Jacob leaky aquifer spreadsheet in addition to estimating $\boldsymbol{T}$. 


\section{Predicting Drawdown in a Confined Aquifer}

Theis, 1935, published the analytical solution for flow to a well in a confined aquifer. The following assumptions apply to the analytical solution:

- Aquifer has infinite extent, and is homogeneous, and isotropic.

- Well discharge is at a constant rate.

- Well fully penetrates the confined aquifer resulting in horizontal flow to the well and flow is laminar.

- Aquifer has uniform thickness and is horizontal.

- The potentiometric surface is horizontal initially

- Aquifer is fully confined and discharge is derived exclusively from storage in the aquifer. The equation for predicting drawdown (s) at the well is as follows:

$$
s=\frac{Q}{4 \pi T} W(u)
$$

where,

$\boldsymbol{s}$ is drawdown $(L)$,

$\boldsymbol{T}$ is transmissivity $\left(\mathrm{L}^{2} / \mathrm{T}\right)$,

$\boldsymbol{Q}$ is the pumping rate $\left(\mathrm{L}^{3} / \mathrm{T}\right)$, and

$W(u)$ is the well function and is the infinite series part of the analytical solution to the nonsteady, radial ground-water flow equation that is approximated by:

$W(u)=-0.577216-\ln u+u-\frac{u^{2}}{2 \cdot 2 !}+\frac{u^{3}}{3 \cdot 3 !}-\frac{u^{4}}{4 \cdot 4 !}+\cdots$

where, $u=\frac{r^{2} S}{4 T t}$

where, $\boldsymbol{S}$ is the aquifer storage coefficient (L/L),

$\boldsymbol{t}$ is time (T), and

$\boldsymbol{r}$ is radial distance from the well $(\mathrm{L})$. 
Instructions for Predicting Drawdown in a Confined Aquifer

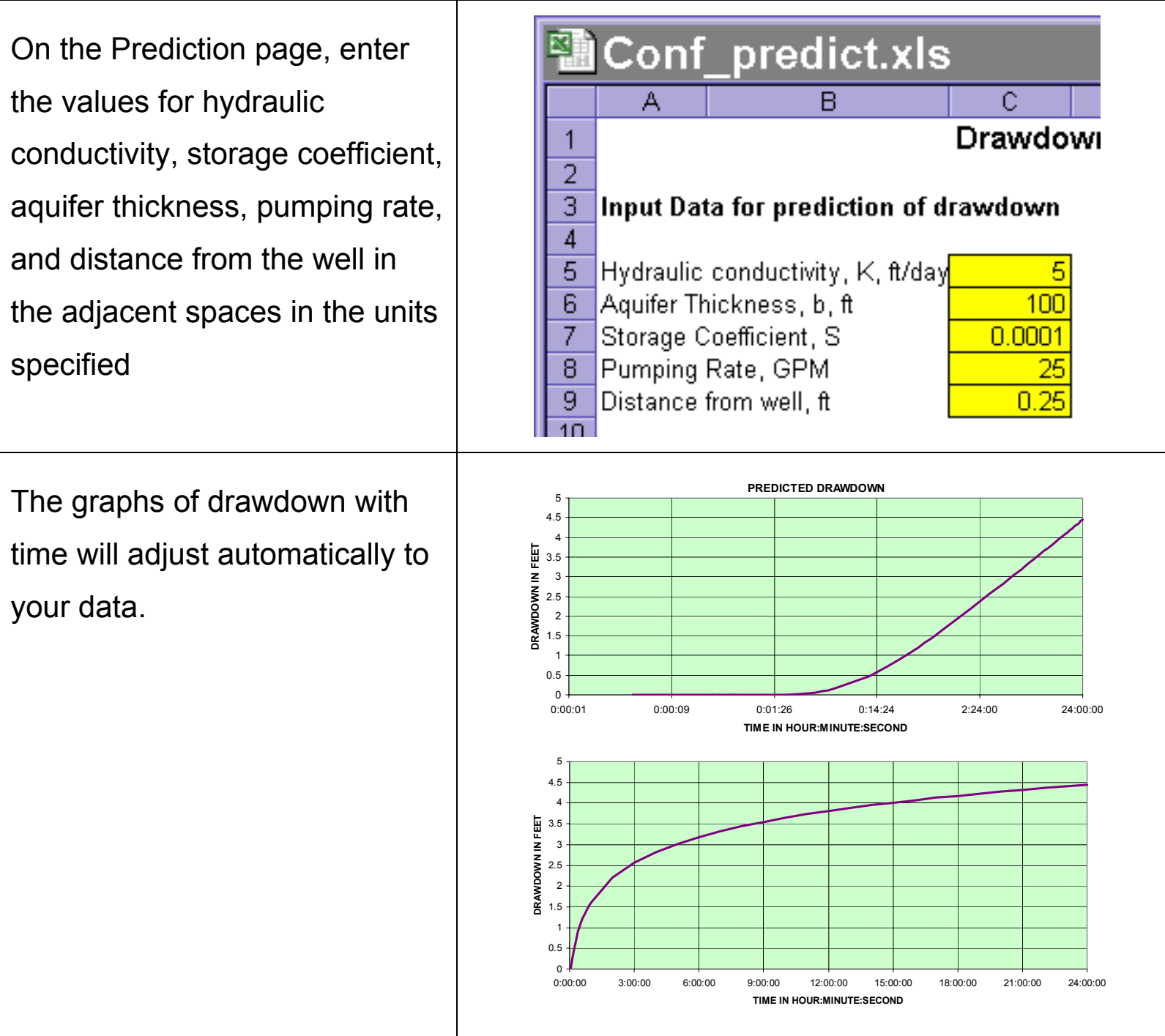




\section{Cooper-Jacob Straight-Line Method}

The Cooper-Jacob method (Cooper and Jacob, 1946), commonly referred to as the straightline method, is a simplification of the Theis (1935) solution for flow to a fully penetrating well in a confined aquifer. The method may be used to analyze data from a single pumping well. The Jacob (1947) equation for predicting drawdown at the well is:

$$
s=\frac{Q}{4 \pi T} \ln \frac{2.25 T t}{r_{w}^{2} S}
$$

where,

$\boldsymbol{T}$ is aquifer transmissivity $\left(\mathrm{L}^{2} / \mathrm{T}\right)$,

$\boldsymbol{Q}$ is the constant discharge rate $\left(\mathrm{L}^{3} / T\right)$,

$S$ is the storage coefficient $(\mathrm{L} / \mathrm{L})$,

$\boldsymbol{s}$ is drawdown (L),

$\boldsymbol{t}$ is time $(\mathrm{T})$, and

$r_{w}$ is the well radius $(L)$.

The same assumptions apply to the Cooper-Jacob analytical solution as the Theis solution, but the well function $\boldsymbol{W}(\boldsymbol{u})$ is calculated for $\boldsymbol{u}<0.01$ in order to neglect all but the first two terms of the infinite series of the well function in the Theis equation. A straight-line approximation of $W(u)$ is adequate for most applications even where $\boldsymbol{u}$ is as great as 0.1 .

For the Cooper-Jacob straight-line method, drawdown is plotted with an arithmetic scale on the $y$-axis versus time plotted with a logarithmic scale on the x-axis. Transmissivity $(\boldsymbol{T})$ is estimated from the pumping rate $(\boldsymbol{Q})$ and the change in drawdown per log-cycle $(\Delta \boldsymbol{s})$ from the following equation:

$$
T=\frac{2.3 Q}{4 \pi} \frac{1}{\Delta s}
$$

where,

$\Delta \boldsymbol{s}$ is change in drawdown per log-cycle (L).

Well losses and partial-penetration have a minimal effect on transmissivity values that are estimated using the Cooper-Jacob method. Well losses and partial penetration affect drawdowns by a fixed amount that changes very little after a well has been discharging for a while (minutes to hours after production begins). Additional drawdown at later times is due to declining heads in the aquifer and the rate of decline is controlled mostly by the transmissivity of the aquifer. Analyzing the change in drawdown at later times negates the effect of a fixed offset due to well losses and partial-penetration on the determination of transmissivity. 
Instructions for Estimation of $\mathrm{K}$ and $\mathrm{T}$ with the Cooper-Jacob Spreadsheet

\section{PASTE DATA}

Add time-series data to the DATA page. The first entry (row 8 ) should be the time pumping began with the static water level.

\section{Adjust headings}

Match units of your data.

Enter the site name, date, well construction, and aquifer properties in the INPUT section on the OUTPUT sheet.

\section{ADD REMARKS}

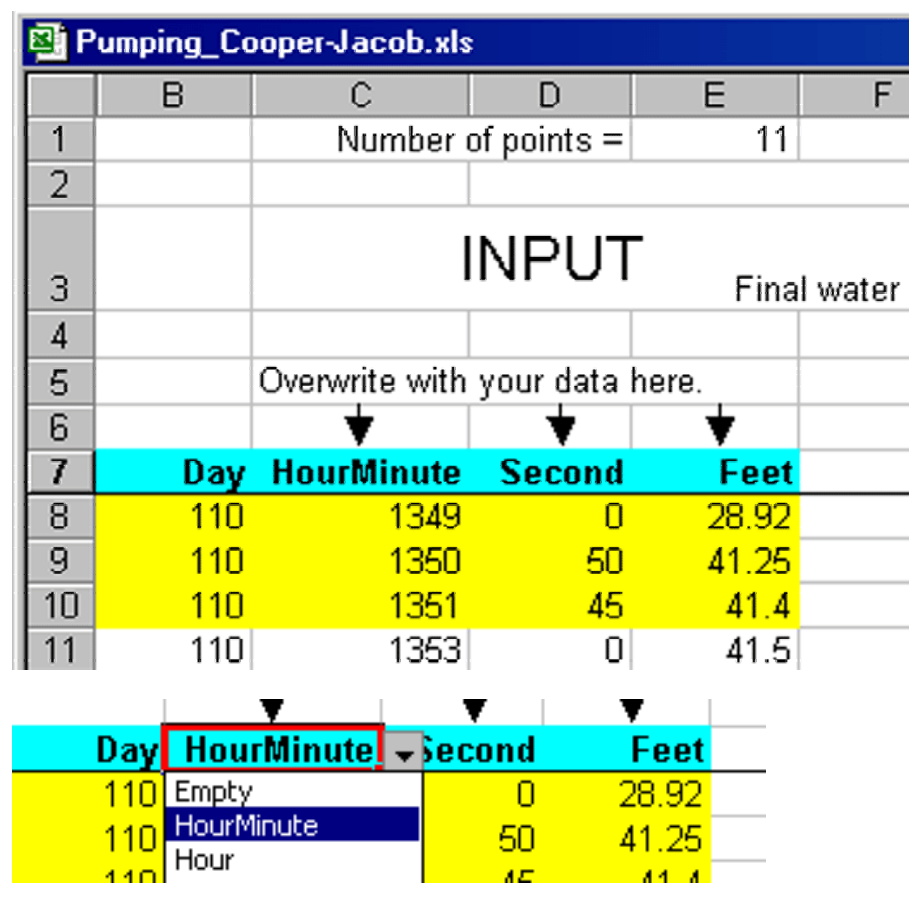

INPUT

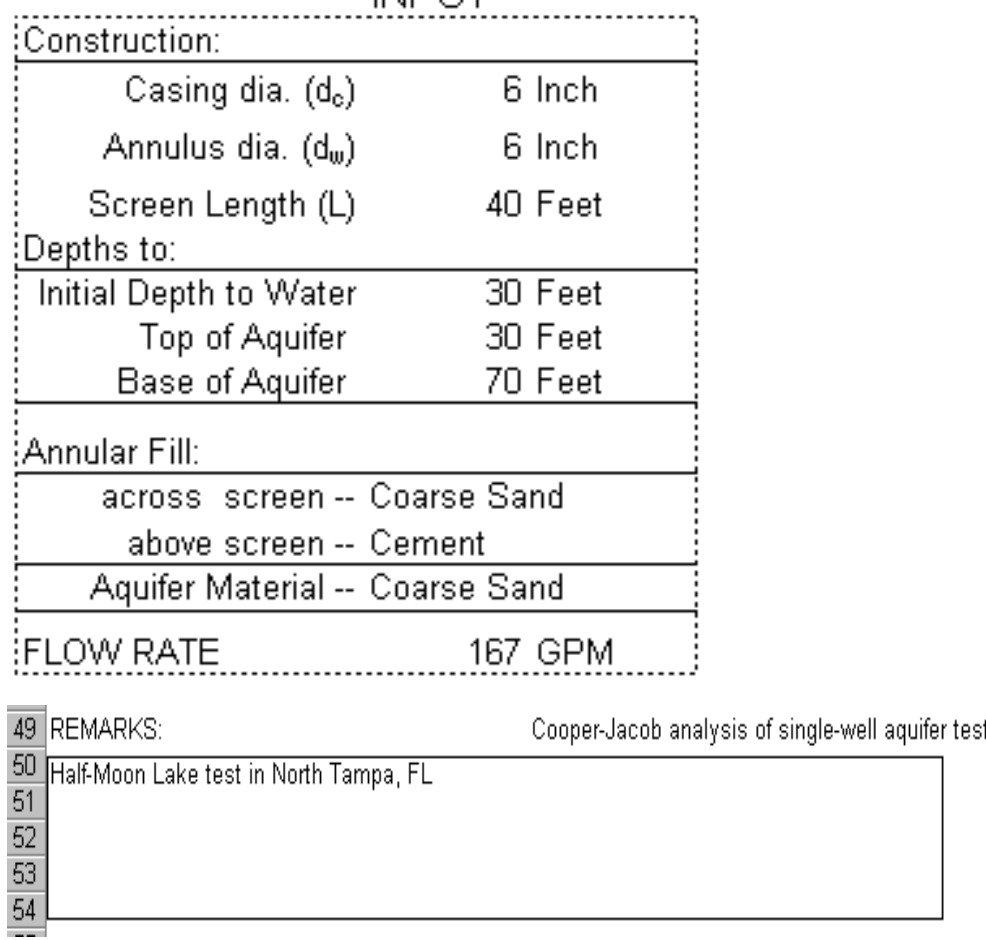




\section{ESTIMATE T}

Estimate transmissivity by grabbing the end of the red line

\section{GET CROSS}

A cross-arrow will appear with 2 clicks (not a doubleclick).

\section{SHIFT TO FIT}

The ends of the red line can be shifted along the $\mathrm{X}$-axis or $Y$-axis until the slope of the line parallels the measured data.
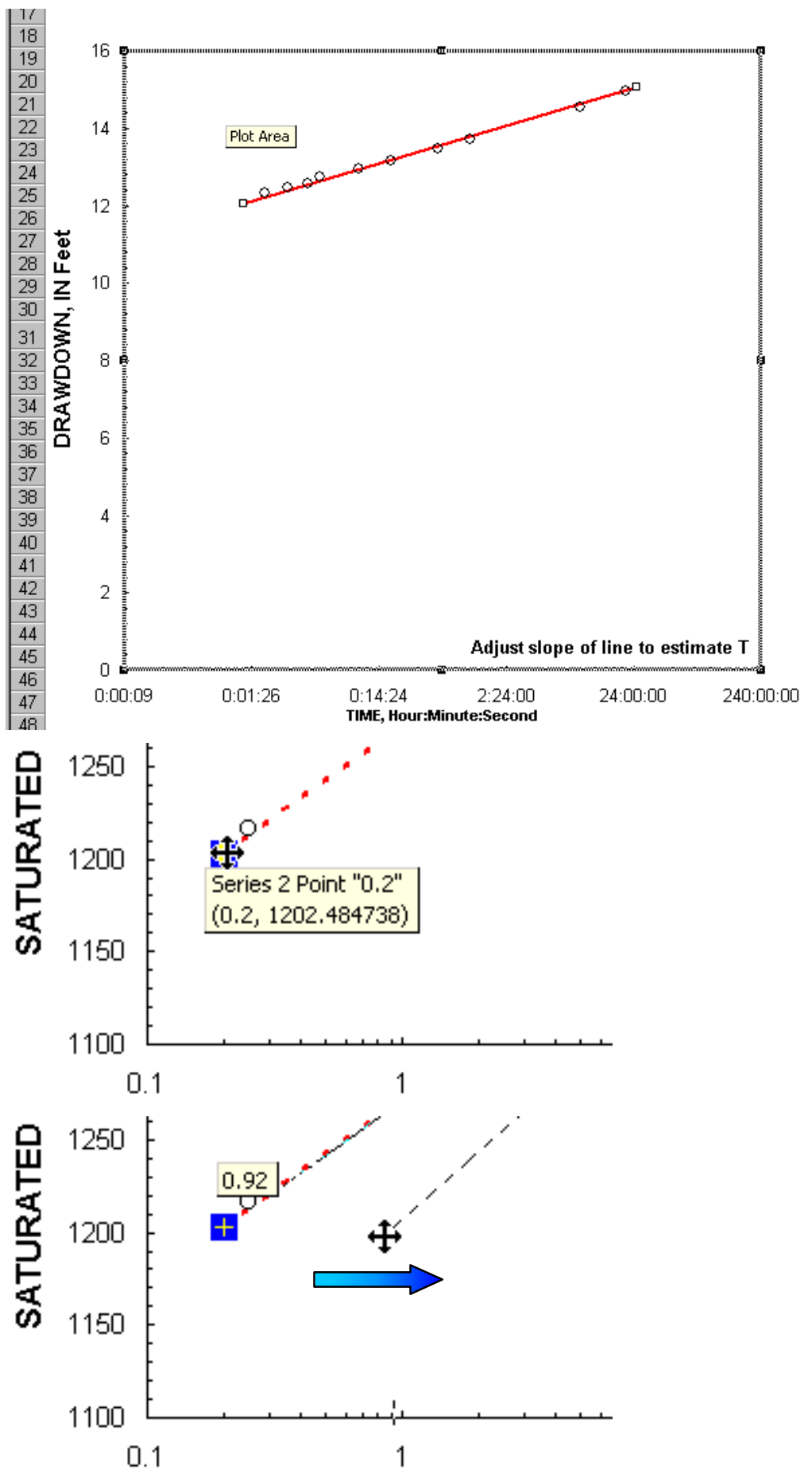


\section{Theis Recovery Data Analysis for Confined Aquifer}

The analysis of recovery data involves the measurement of the rise in water levels, also referred to as residual drawdowns, following the cessation of a period of pumping at a constant rate. The analytical method is based on the Theis theory and applies to confined aquifers with fully penetrating wells. The method relies on the theory of superposition in that the water-level rise after the test is assumed to be the combined response to an imaginary well recharging the aquifer and continued pumping. Imaginary recharge occurs at an identical rate to the constant discharge during the pumping test. The equation for residual drawdown after a pumping test with constant discharge is:

$$
s^{\prime}=\frac{Q}{4 \pi T}\left\{W(u)-W\left(u^{\prime}\right)\right\}
$$

Where,

$$
u=\frac{r^{2} s}{4 T t} \text { and } u^{\prime}=\frac{r^{2} s}{4 T t^{\prime}}
$$

$\boldsymbol{t}$ is the time from the start of pumping (T),

$t^{\prime}$ is the time from the cessation of pumping $(T)$,

$S$ is the storage coefficient $(L / L)$,

$Q$ is the pumping rate $\left(L^{3} / T\right)$,

$\boldsymbol{s}^{\prime}$ is the residual drawdown (L),

If $\boldsymbol{u}$ and $\boldsymbol{u}^{\prime}$ are small, less than 0.01 , then the above equation can be simplified to:

$$
s^{\prime}=\frac{2.3 Q}{4 \pi T} \log _{10}\left(\frac{t}{t^{\prime}}\right)
$$

A semilog plot of $\boldsymbol{s}^{\prime}$ versus $\boldsymbol{t} / \boldsymbol{t}^{\prime}$ will yield a straight line. The slope of which is:

$$
\Delta s^{\prime}=\frac{2.3 Q}{4 \pi T}
$$

where, $\Delta \boldsymbol{s}^{\prime}$ is the change in residual drawdown in one log cycle of $\boldsymbol{t} / \boldsymbol{t}^{\prime}$. The same assumptions for the Cooper-Jacob, straight-line method must be met, and the flow to the well is in an unsteady state when $\boldsymbol{t}^{\prime}>\left(25 \boldsymbol{r}^{2} \boldsymbol{S}\right) \boldsymbol{T}$ and $\boldsymbol{u}<0.01$

The spreadsheet is similar to the Cooper-Jacob spreadsheet. $\boldsymbol{T}$ and $\boldsymbol{K}$ are estimated in the same way. Enter information into the DATA and OUTPUT sheets and adjust the red line until it fits the plotted data on the OUTPUT page. 


\section{Jacob-Lohman Method for a Flowing Well in a Confined Aquifer}

This method is for analysis of flowing artesian wells. It was applied by Jacob and Lohman, 1952. For application of this method, a flowing well is capped or has an above ground stand pipe for measuring the initial water level or pressure head. It is then allowed to flow. The outlet elevation is a constant head and the discharge gradually decreases. Thus, this is also known as a constant drawdown variable discharge test. This is analogous to the heat flow equation solved by Smith (1937) for heat-flow in an infinite solid bounded by an internal cylinder.

The equation for flow to the well is:

$$
Q=2 \pi T\left(h_{\circ}-h\right) G(\alpha)=2 \pi T s_{w} G(\alpha)
$$

where,

$\mathbf{G}(\alpha)$ is a complex integral that is approximated numerically (d'less),

$\boldsymbol{h}_{\mathrm{o}}$ is the static head before uncapping the well or allowing it to flow $(\mathrm{L})$,

$\boldsymbol{h}$ is the head after opening the well, or the elevation of the opening $(L)$,

$\boldsymbol{s}_{w}$ is the constant drawdown or $\boldsymbol{h}_{\mathrm{o}}-\boldsymbol{h}(\mathrm{L})$, and

$\alpha$ is a dimensionless group that is similar to $u, \alpha=\frac{T t}{S r_{w}^{2}}$.

One of the difficulties is estimating the effective radius of the well $\left(\boldsymbol{r}_{w}\right)$ but $\boldsymbol{T}$ estimates are not affected by $\boldsymbol{r}_{\boldsymbol{w}}$ for a single well analysis. Jacob and Lohman (1952) used the borehole diameter as the estimate of well radius rather than the casing or screen diameter.

The Jacob-Lohman method is very similar to the Cooper-Jacob method and shares the same assumptions. The graphical procedure is similar to the recovery analysis. The group $\boldsymbol{s}_{w} / \boldsymbol{Q}$ is plotted on a Cartesian axis and $\boldsymbol{t}$ is plotted on a logarithmic axis. The change in $\boldsymbol{s}_{w} / \boldsymbol{Q}$ for one log cycle of $\boldsymbol{t}$ is used to estimate $\boldsymbol{T}$ and the intercept could be used to estimate $\boldsymbol{S}$. Storage is not estimated or reported because well losses displace the $\boldsymbol{S} / \boldsymbol{Q}$ curve upward which may cause $\boldsymbol{S}$ to be grossly underestimated.

$$
T=\frac{2.3}{4 \pi} \frac{1}{\Delta\left(s_{w} / Q\right)}
$$

where, $\Delta\left(s_{w} / Q\right)$ is the change in $\boldsymbol{s}_{w} / \boldsymbol{Q}$ for one log cycle of $\boldsymbol{t}$.

This spreadsheet works much like the Cooper-Jacob and Recovery analysis spreadsheet. Enter information into the DATA and OUTPUT sheets and adjust the red line until it fits the plotted data on the OUTPUT page. 


\section{Step-Drawdown Methods}

A step-drawdown test is a single-well test that is frequently conducted after well development to determine the correct sizing of the production pump and the efficiency of the well. Thus, these data are more common than multi-well aquifer-test data, but not as common as specific-capacity data. The step-drawdown spreadsheet was developed primarily for estimating transmissivity from existing data sets. Transmissivity can be estimated less ambiguously from a single-well that is pumped at a high, constant rate and analyzed with the Cooper-Jacob method. The first step of the test is accomplished by pumping at a relatively low, constant discharge until the water level in the well stabilizes. For the second and additional steps, discharge is increased to a new constant rate that is held constant again until the water level stabilizes. This must be done at least 3 times with the pumping rate held constant until the change in drawdown is small (1-4 hours per step). The conceptual model assumes that drawdown in the well is related to well losses and aquifer losses according to the equation:

$$
s_{w}=B(t) Q+C Q^{n}
$$

where $\boldsymbol{s}_{w}$ is the total drawdown at the well (L),

$B(t) Q$ is the drawdown related to the discharge from an aquifer that meets the Theis (1935) assumptions. $B(t)$ is the aquifer loss coefficient;

$$
B(t)=\left(\frac{2.3}{4 T \pi}\right) \log _{10}\left(\frac{2.25 T t}{r^{2} S}\right) \text { from the Cooper-Jacob equation (1946). }
$$

$C Q^{n}$ is the drawdown related to wellbore damage and screen losses $(L)$,

C is a well loss coefficient, and

$\boldsymbol{n}$ is an exponent of 1 or greater.

The variables $\boldsymbol{C}$ and $\boldsymbol{n}$ are dependent on the extent to which turbulence develops in the near well environment. Estimates of $\boldsymbol{n}$ ranged from 1.5 to 3.5 in several water well applications (Rorabaugh, 1953).

Well losses were approximated with $\boldsymbol{n}$ equal to 1 because the friction losses can be characterized in terms of $\boldsymbol{K}$ for comparison with the hydraulic conductivity of the aquifer. Well losses were assumed to occur in the space between the well casing and the face of the drilled hole. This is an arbitrary assumption that probably is not true because head losses occur across the well screen and any damaged zone around the wellbore. However, an outer diameter to a well-loss zone is needed to define friction losses in terms of $\boldsymbol{K}$. The hydraulic conductivity of the annular space is

$$
K_{\text {ANNULAR }}=\frac{2.3 \log _{10}\left(r_{w} / r_{C}\right)}{2 \pi C L}
$$

where $\boldsymbol{r}_{\boldsymbol{W}}$ is the radius of the annular space,

$r_{c}$ is the radius of the well casing $(L)$,

$L \quad$ is the screen length $(L)$. 
Head losses due to well entry and formation damage around the well can alternatively be described by skin, a term commonly used in petroleum engineering (Earlougher, 1977). Skin lumps the effects of hydraulic conductivity differences and an effective diameter of wellbore damage into a single term because the two terms behave as a lumped parameter. If an arbitrary diameter of wellbore damage is defined, skin can be described in terms of a hydraulic conductivity contrast $\left(K / K_{A N N U L A R}\right)$ by

$$
\text { skin }=2.3\left(\frac{K}{K_{A N N U L A R}}-1\right) \log _{10}\left(\frac{r_{W}}{r_{C}}\right)_{\text {where, }}
$$

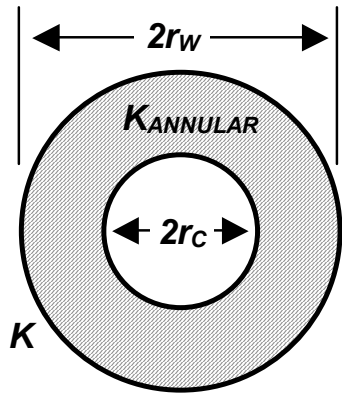

The relation between skin and the reduction of hydraulic conductivity around the wellbore is best illustrated by example. For an annular ring of damaged material where $\boldsymbol{r}_{w}=\mathbf{2} \boldsymbol{r}_{c}$, skin values of 1 , 2 , and 4 yield $K / K_{\text {ANNULAR }}$ values of $0.41,0.26$, and 0.15 .

Transmissivity is estimated with a straight line that is fitted to a plot of $\frac{\boldsymbol{S}}{\boldsymbol{Q}_{\text {NSTEP }}}$ against $\sum_{i=1}^{N S T E P} \frac{\log \left(\Delta t_{i}\right) \Delta Q_{i}}{Q_{N S T E P}}$

(Lee, 1982) (fig. 4) where $\Delta \boldsymbol{t}_{\boldsymbol{i}}$ is the elapsed time since the beginning of the $\boldsymbol{i}^{\mathrm{t}}$ step, $\Delta \boldsymbol{Q}_{\boldsymbol{i}}$ is the change in discharge at the beginning of the $\boldsymbol{i}^{\boldsymbol{t}}$ step, and $\boldsymbol{Q}_{\boldsymbol{N S T E P}}$ is the discharge when $\boldsymbol{s}$ was measured. The straight-line analysis is similar to a Cooper-Jacob analysis once drawdowns and discharges have been transformed. Transmissivity is related to the slope of the fitted line $\left(\boldsymbol{m}^{\prime}\right)$ by

$$
T=\frac{2.3}{4 \pi} \frac{1}{m^{\prime}}
$$

Unlike the Cooper-Jacob solution, discharge $(\boldsymbol{Q})$ is not in the equation because variable discharge rates are incorporated in the slope $\left(\boldsymbol{m}^{\prime}\right)$.

$K_{\text {ANNULAR }}$ is estimated by fitting simulated drawdowns to measured drawdowns in a secondary plot (fig. 5). A reasonable storage value must be assigned by the user because storage and $\boldsymbol{K}_{\text {ANNULAR }}$ cannot be estimated independently. The estimate of $\boldsymbol{T}$ is not affected by changes in estimates of storage and $\boldsymbol{K}_{\text {ANNULAR }}$. 


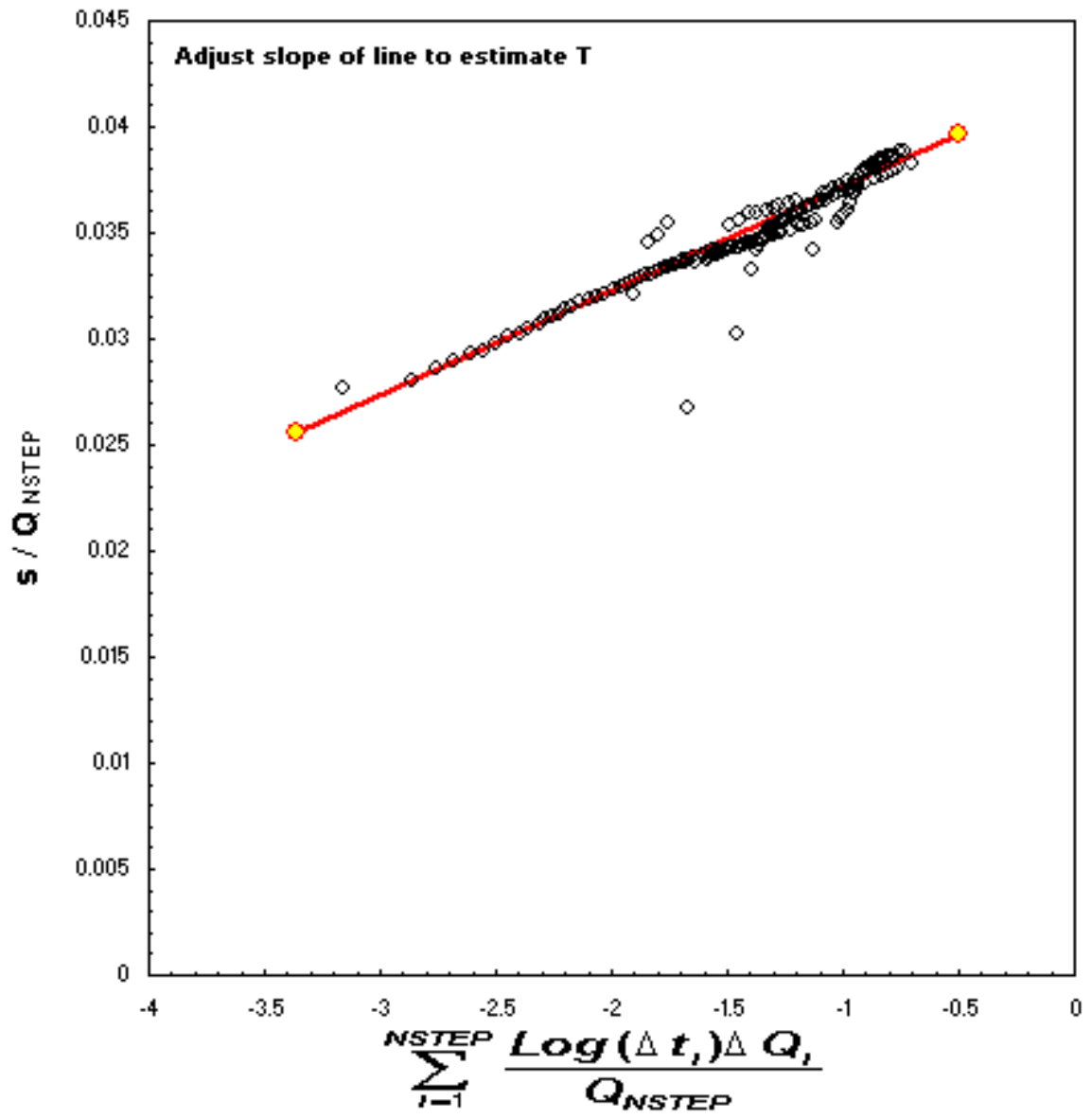

Figure 4. Plot used to estimate transmissivity from the step-drawdown spreadsheet. 

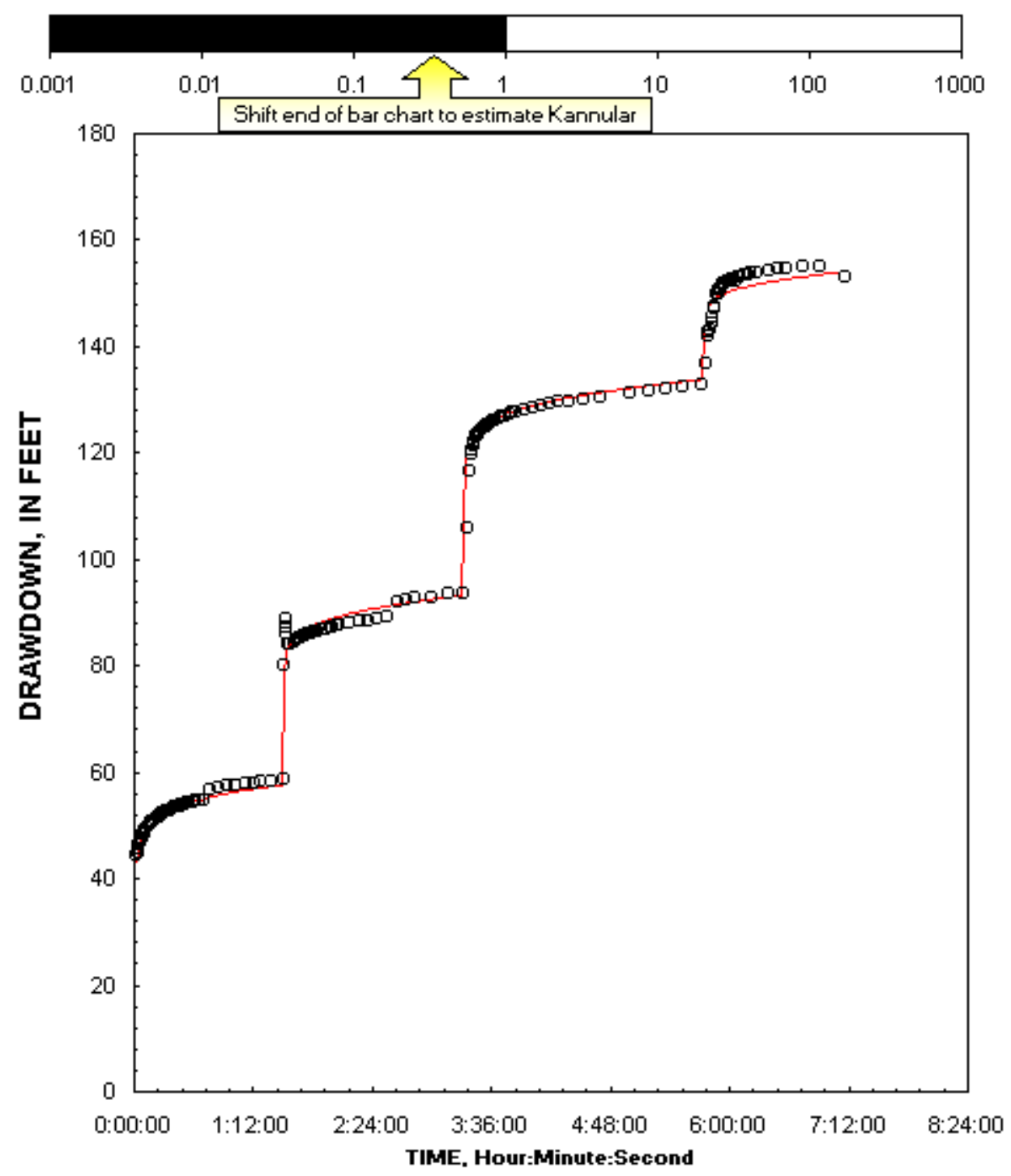

Figure 5. Graph used for estimating hydraulic conductivity of annular space and skin. 
Instruction for Estimation of $\boldsymbol{T}$ and $\boldsymbol{K}$ from the Step Drawdown Spreadsheet

\section{PASTE DATA}

Add water-level data on the WATERLEVEL DATA sheet and select units as with previous sheets.

Paste discharge data to the FLOW RATES sheet and select units as with previous sheets.

Enter the site name, date, well construction, aquifer properties, and storage coefficient in the INPUT section on the OUTPUT sheet.

\begin{tabular}{|c|c|c|c|c|c|c|c|}
\hline \multirow{2}{*}{$\frac{3}{4}$} & \multicolumn{3}{|c|}{ WATER-LEVEL INPUT } & \multicolumn{2}{|c|}{ Final water level, in Feet $=$} & \multirow[t]{2}{*}{590.04} & \multirow[b]{4}{*}{ Drawdown } \\
\hline & & & & & & & \\
\hline 5 & & \multicolumn{3}{|c|}{ Overwrite with your data here. } & & & \\
\hline 6 & & $\frac{1}{7}$ & $\checkmark$ & $\downarrow$ & & & \\
\hline 7 & Empty & Empty & DateTime & Feet & Hr:Min:Sec & $\Delta t$, days & Feet \\
\hline 8 & & & 8:00:00 & 434.90 & 8:00:00 & & \\
\hline 9 & & & 8:01:00 & 479.24 & 8:01:00 & $0: 01: 00.0$ & 44.340 \\
\hline 10 & & & 8:02:00 & 479.82 & 8:02:00 & $0: 02: 00.0$ & 44.920 \\
\hline 11 & & & 8:02:30 & 480.66 & $8: 02: 30$ & $0: 02: 30.0$ & 45.760 \\
\hline
\end{tabular}

\begin{tabular}{|c|c|c|c|}
\hline 可 & umping_StepD & wdown.xis & \\
\hline & $\bar{B}$ & $\mathrm{C}$ & $\mathrm{D}$ \\
\hline 1 & Numb & $r$ of points $=$ & 4 \\
\hline 2 & & & \\
\hline 3 & PUMF & AGE & DUT \\
\hline 4 & & & \\
\hline 5 & Overwrite with & lischarge rat & here. \\
\hline 6 & $\checkmark$ & $\downarrow$ & $\checkmark$ \\
\hline 7 & Empty & DateTime & GPM \\
\hline 8 & & 8:00 & 1600 \\
\hline 9 & & $9: 30$ & 2500 \\
\hline 10 & & $11: 19$ & 3500 \\
\hline 11 & & $13: 45$ & 4000 \\
\hline & & INPUT & \\
\hline Cons & truction: & & \\
\hline & Casing dia. ( & 18 & \\
\hline & Annulus dia. (c & & \\
\hline & Screen Length & 1350 & \\
\hline Dept & is to: & & \\
\hline & water level (DT) & 438 & \\
\hline & Top of Aquif & & \\
\hline & Base of Aquif & 1955 & \\
\hline Annu & lar Fill: & & \\
\hline & $\begin{array}{l}\text { across screen } \\
\text { above screen }\end{array}$ & $\begin{array}{l}\text { - Gravel } \\
\text { - Cement }\end{array}$ & \\
\hline & quifer Material & -- Fine Sand & \\
\hline & ASSUMED S & 0.0004 & less \\
\hline
\end{tabular}




\section{ESTIMATE T}

Go to the OUTPUT sheet. Select red line. NOTE-changing this line affects the second graph.

\section{GET CROSS}

A cross-arrow will appear with 2 clicks (not a double-click).

\section{SHIFT TO FIT}

The ends of the red line can be shifted along the $\mathrm{X}$-axis or $Y$-axis until the slope of the line parallels the measured data.
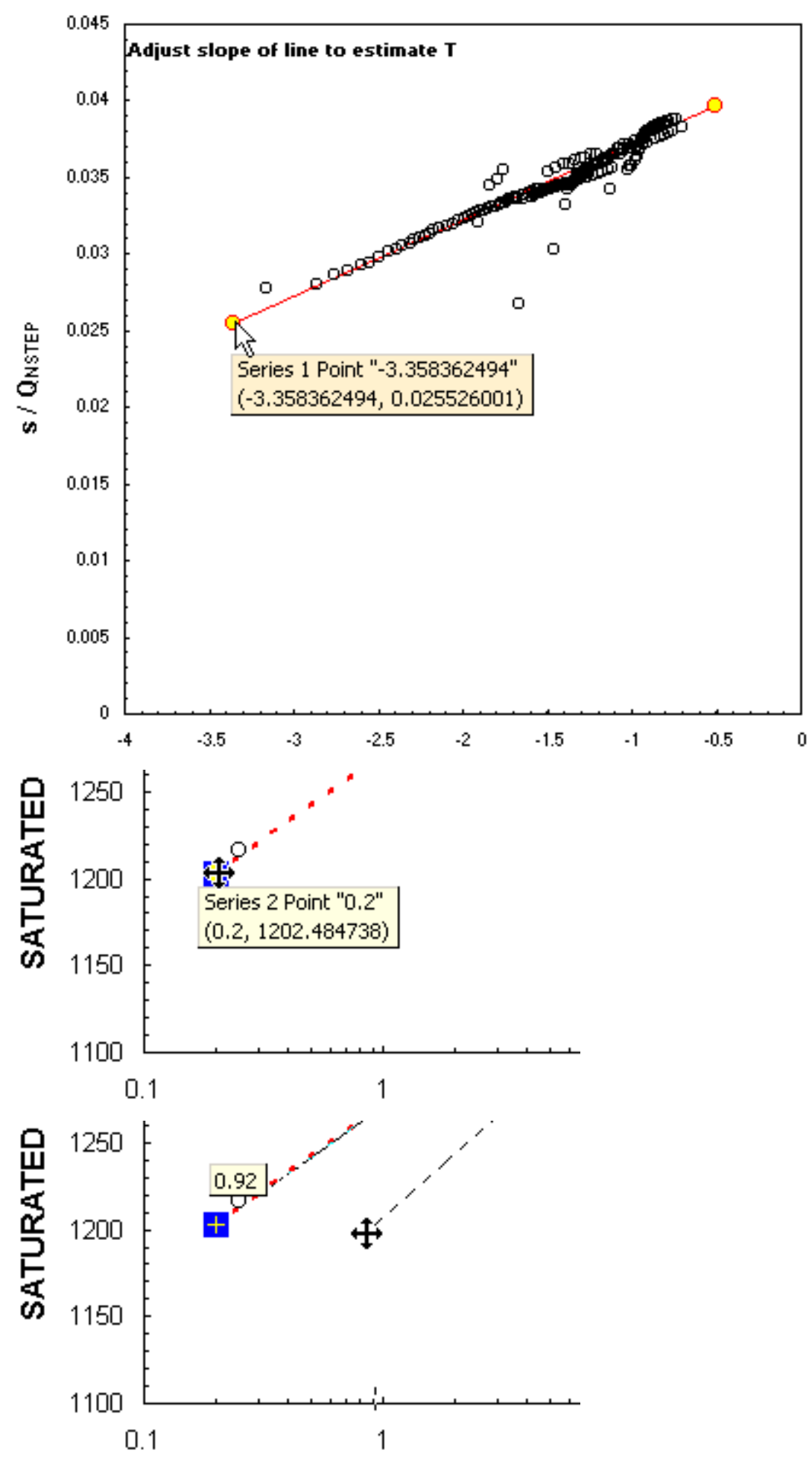


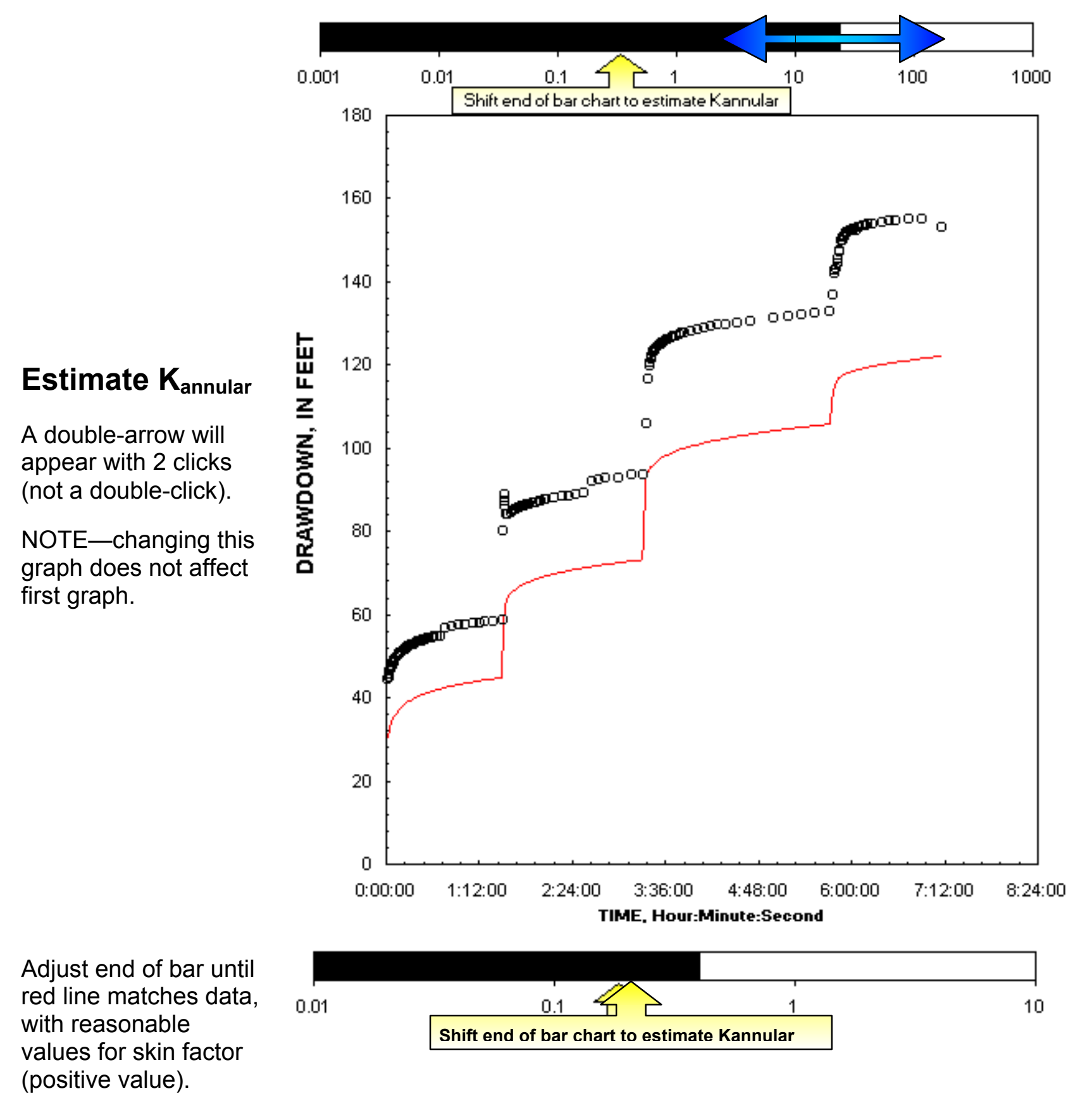




\section{Distance-Drawdown Methods}

The distance-drawdown methods can be used for multi-well aquifer-test data once the drawdown has reached quasi-steady-state. A quasi-steady-state is reached after $\boldsymbol{u}$ is less than 0.01 at the well furthest from the pumping well. Most of the water released from storage originates beyond the wells that are being analyzed once quasi-steady-state conditions are established. Distance-drawdown is a simple graphical method (Weissman and others, 1977). The equations for computing the transmissivity $(\boldsymbol{T})$ of confined aquifers and hydraulic conductivity $(\boldsymbol{K})$ of unconfined aquifers are:

$$
\begin{aligned}
& T=\frac{Q}{2 \pi} \frac{2.3 \log _{10}\left(\frac{r_{2}}{r_{1}}\right)}{s_{1}-s_{2}} \text { Confined solution for transmissivity } \\
& K=\frac{Q}{\pi} \frac{2.3 \log _{10}\left(\frac{r_{2}}{r_{1}}\right)}{h_{2}^{2}-h_{1}^{2}} \text { Unconfined solution for hydraulic conductivity }
\end{aligned}
$$

where, $\boldsymbol{T}$ is transmissivity $\left(\mathrm{L}^{2} / \mathrm{T}\right)$,

$K$ is hydraulic conductivity $(\mathrm{L} / \mathrm{T})$,

$\boldsymbol{Q}$ is the pumping rate $\left(\mathrm{L}^{3} / T\right)$,

$S$ is drawdown at well 1 or $2(L)$,

$\boldsymbol{h}$ is saturated thickness at well 1 or $2(L)$,

$r \quad$ is the radial distance from the pumping well at well-1 or well-2 $(L)$.

The following assumptions apply to the confined and unconfined aquifer analytical solution:

- Aquifer is homogeneous, isotropic, and of infinite extent.

- Well discharge is at a constant rate.

- Well is of infinitesimal diameter and well losses are minimal.

- Well fully penetrates the aquifer.

- System is at steady-state or equilibrium. Storage cannot be estimated.

- For unconfined flow, the Dupuit-Forchheimer condition is invoked which assumes that flow is nearly horizontal and vertical gradients can be neglected (Fetter, 1994). 
Transmissivity or hydraulic conductivity are estimated by fitting a straight line to water-level data at several log-radial distances from the production well. The transmissivity of confined aquifers is estimated by plotting drawdown versus log-radial distance. The hydraulic conductivity of unconfined aquifers is estimated by plotting saturated thickness squared versus log-radial distance. Unconfined or confined conditions are determined from the well construction data and the static depth to water entered into the INPUT fields on the OUTPUT sheet.

Instructions for Distance-Drawdown Spreadsheet

Paste data on the sheet DATA

Distance can be specified as radial distance from the production well or as XY pairs. Radial distances should be entered in column C or D. XY pairs should be entered in columns $\mathrm{C}$ and $\mathrm{D}$.

Row 8 is reserved for the production well.

Adjust the headings to match the units of distance and water-level change columns.

Enter the site name, date, well construction, and aquifer properties in the INPUT section on the OUTPUT sheet.

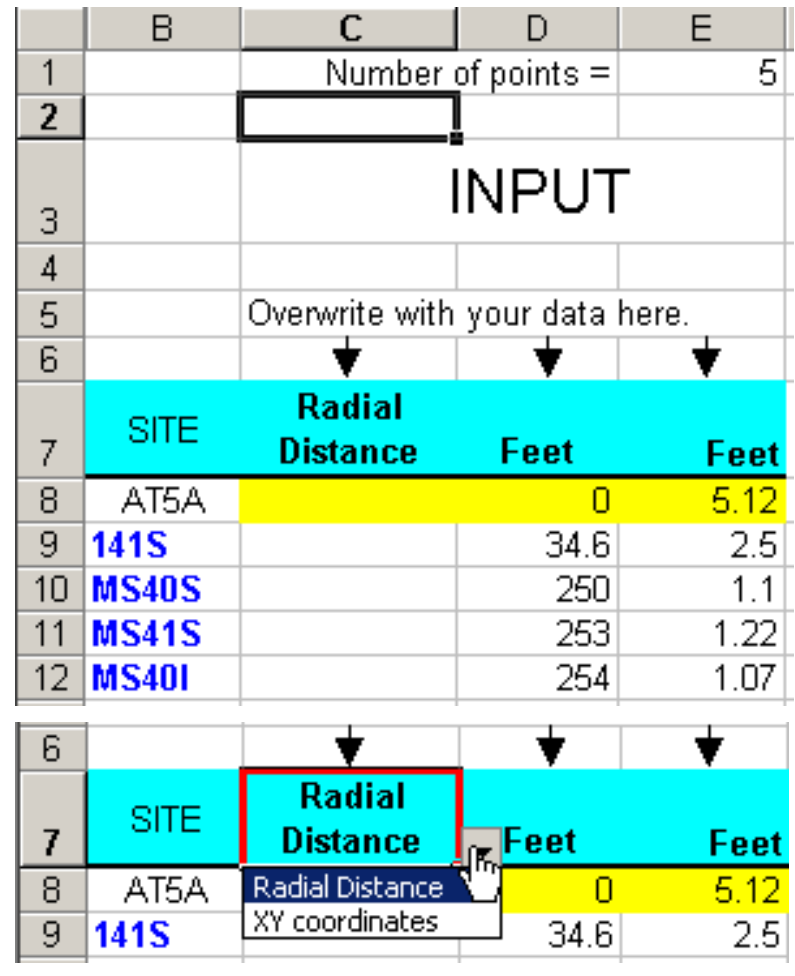

\begin{tabular}{|c|c|}
\hline \multicolumn{2}{|l|}{ Construction: } \\
\hline Casing dia. $\left(\mathrm{d}_{\mathrm{c}}\right)$ & 6 Inch \\
\hline Annulus dia. $\left(\mathrm{d}_{w}\right)$ & 6 Inch \\
\hline $\begin{array}{l}\text { Screen Length (L) } \\
\text { Depths to: }\end{array}$ & 40 Feet \\
\hline $\begin{array}{c}\text { Initial Depth to Water } \\
\text { Top of Aquifer } \\
\text { Base of Aquifer }\end{array}$ & $\begin{array}{l}30 \text { Feet } \\
30 \text { Feet } \\
70 \text { Feet }\end{array}$ \\
\hline \multicolumn{2}{|l|}{ Annular Fill: } \\
\hline \multicolumn{2}{|c|}{$\begin{array}{l}\text { across screen -- Coarse Sand } \\
\text { above screen -- Cement }\end{array}$} \\
\hline \multicolumn{2}{|c|}{ Aquifer Material -- Coarse Sand } \\
\hline FLOW RATE & $167 \mathrm{GPM}$ \\
\hline
\end{tabular}




\section{PRESS BUTTON}

Press the GROSS FIT button to get an initial estimate from a linear regression. This feature automatically compensates for the extreme differences between fitting confined drawdowns and unconfined values of $\boldsymbol{h}^{2}$.

The GROSS FIT button will not work if macros are not enabled.

\section{REFINE ESTIMATE}

Estimate hydraulic conductivity by grabbing the end of the red line.

\section{GET CROSS}

A cross-arrow will appear with 2 clicks (not a double-click).

\section{SHIFT TO FIT}

The ends of the red line can be shifted along the $\mathrm{X}$-axis or $\mathrm{Y}$-axis until the slope of the line parallels the measured data.

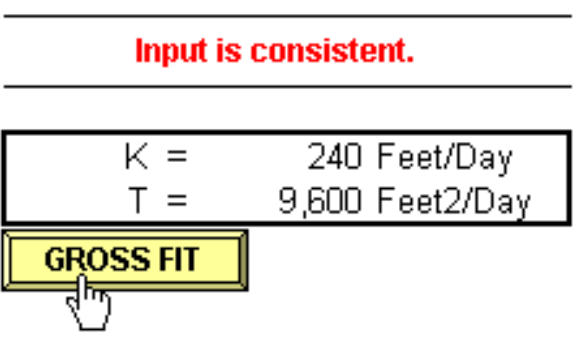

\section{Adjust slope of line to estimate T}
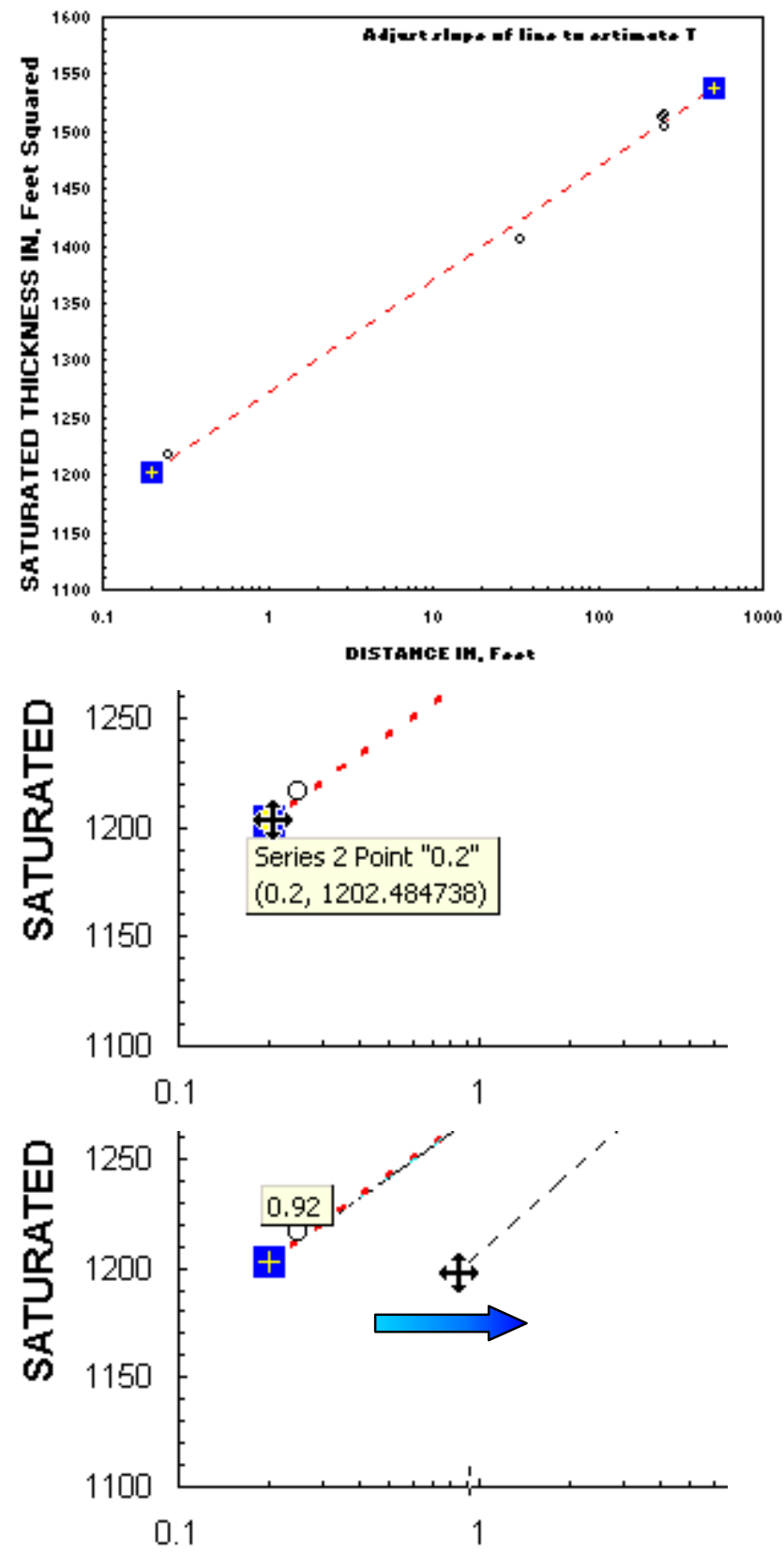


\section{Hantush-Jacob Leaky Aquifer Method}

It's rare in nature to find well-confined aquifers. Thus, for many aquifer tests, water is contributed from the relatively less permeable confining units, in addition to the aquifer that is pumped. Hantush and Jacob (1955) presented a solution for drawdown in a pumped aquifer that has an impermeable base and a leaky confining unit above. Conceptually, this would be a four-layer system, from top to bottom, a water-table aquifer, a leaky confining unit, a confined aquifer, and an extremely low permeability bedrock. During the early time of pumpage, water is coming out of storage from the pumped aquifer and the leaky confining unit. Eventually, the discharge comes into equilibrium with the leakage through the confining unit from the unstressed aquifer and the system is at steady-state. This spreadsheet is based on the equation for drawdown of a well pumped at a constant discharge rate in a leaky aquifer (Hantush and Jacob, 1955).

$$
s=\frac{Q}{4 \pi T} W(u, r / B)
$$

where, $\quad \boldsymbol{u}=\frac{\boldsymbol{r}^{2} \boldsymbol{S}}{\mathbf{4 T t}}$ is dimensionless time,

$$
\frac{1}{B}=\sqrt{\frac{K_{z} / b^{\prime}}{T}}
$$

$\boldsymbol{s}$ is drawdown at the well $(L)$,

$Q$ is the constant discharge rate at the well $\left(\mathrm{L}^{3} / \mathrm{T}\right)$,

$\boldsymbol{r}$ is radial distance from the well $(\mathrm{L})$,

$\boldsymbol{T}$ is transmissivity of the aquifer $\left(\mathrm{L}^{2} / \mathrm{T}\right)$.

$K_{z} / b^{\prime}$ is the leakance $(1 / T)$, where $K_{z}$ is vertical hydraulic conductivity of the confining unit (L/T) and $\boldsymbol{b}^{\prime}$ is thickness of the confining unit $(\mathrm{L})$.

Hantush-Jacob is not a very good method of analysis if the intent of a test is to estimate the leakance of an adjacent confining unit. Confining unit compressibility and storage are usually significant but are assumed away in the Hantush-Jacob solution. All observation wells are assumed to be in the pumped aquifer so leakage from above and below cannot be differentiated. Numerical models are a better means of analyzing an aquifer test with several observation wells that are not in the pumped aquifer.

The spreadsheet is set up for four-observation well datasets, but only three-wells are in the current example spreadsheet, which was developed using data from aquifer tests in the Vekol Valley, Arizona (Marie and Hollet, 1996). The assumptions for the analysis are:

- $\quad$ Aquifer and confining unit are homogeneous, isotropic, and of infinite extent.

- $\quad$ Aquifer is leaky, horizontal flow in stressed aquifer, and vertical flow through confining unit.

- $\quad$ Pumping well is fully penetrating.

- Drawdown in the water-table or unstressed aquifer is negligible. 
- Well storage can be neglected (the pumping well diameter is small).

- Water instantaneously comes out of storage in the aquifer.

- $\quad$ Confining unit storage is negligible. 
Instructions for Estimation of $\boldsymbol{T}$ and $\boldsymbol{K}$ from the Hantush-Jacob Spreadsheet

\section{PASTE DATA}

Paste data specific to each well on the Well-1, Well-2, Well-3, or Well-4, pages.

Well specific data includes the name, radial distance from the production well, and series of time and water-level measurements.

The first entry (row 10) should contain the time pumping began and the static water level.

\section{ADJUST HEADINGS}

Match units of your data.

Enter the site name, date, production well construction, aquifer properties, and confining unit thickness in the INPUT section on the OUTPUT sheet.

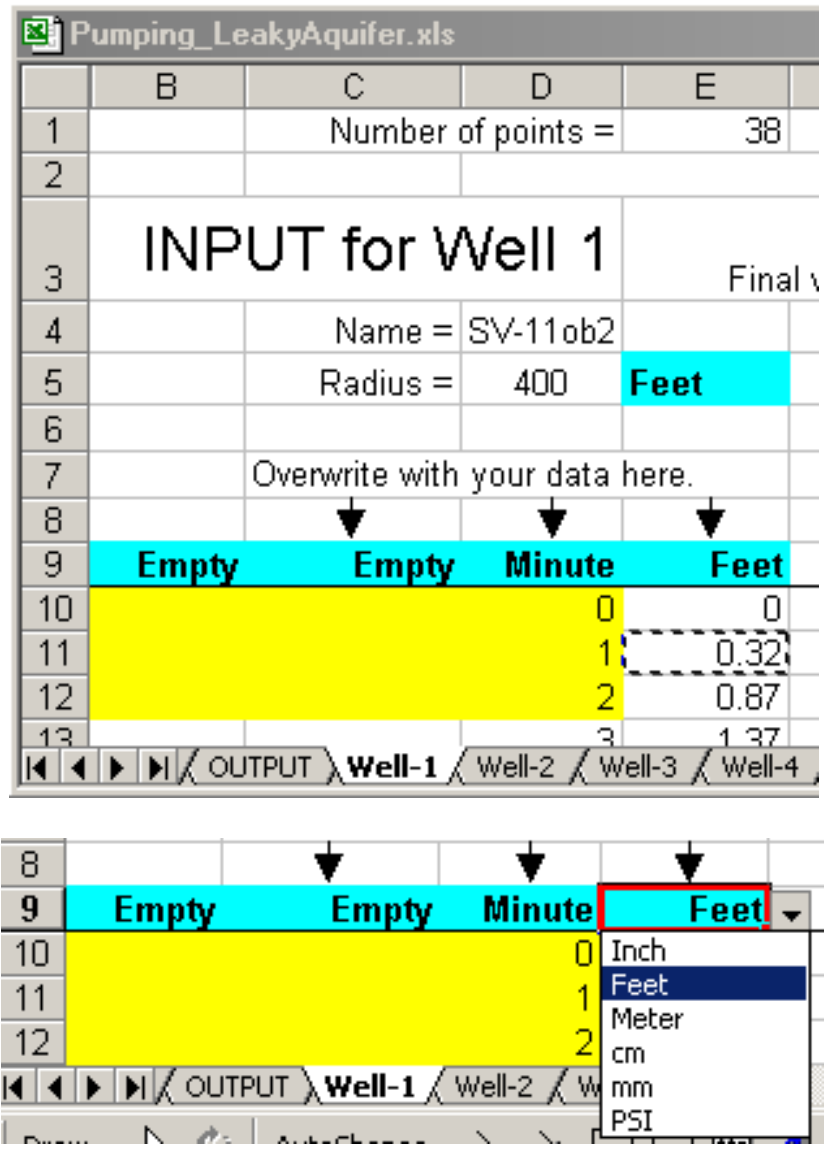

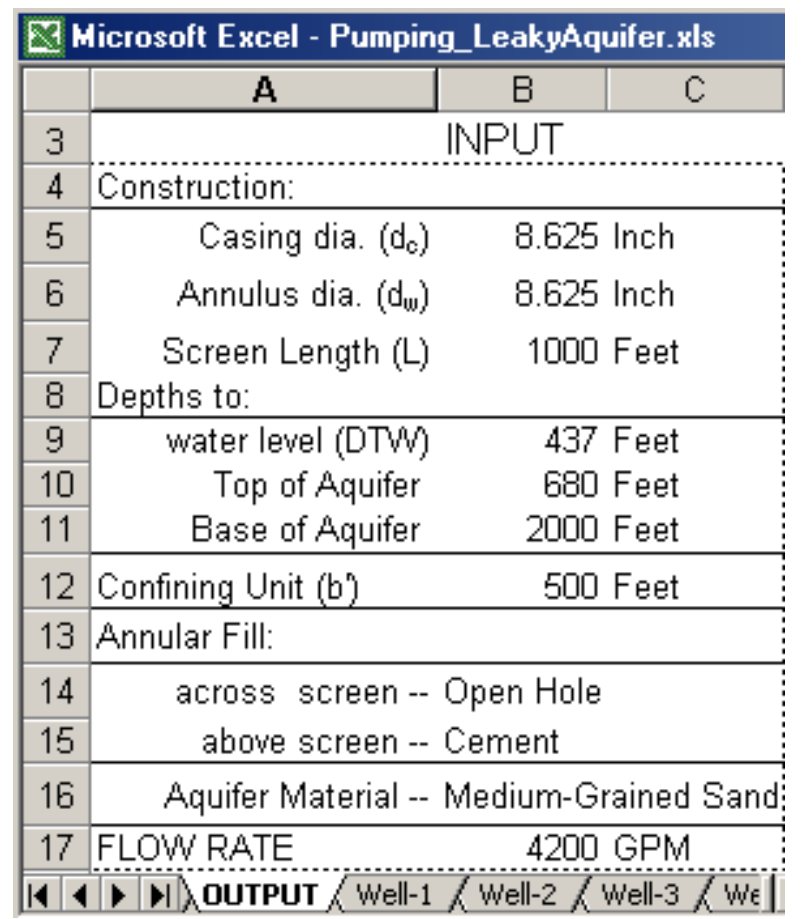




\section{ESTIMATE T and S}

Select yellow line and adjust to match slope and average position of measured drawdowns. Slope determines the transmissivity estimate the average $t / r^{2}$ position determines the storage estimate.

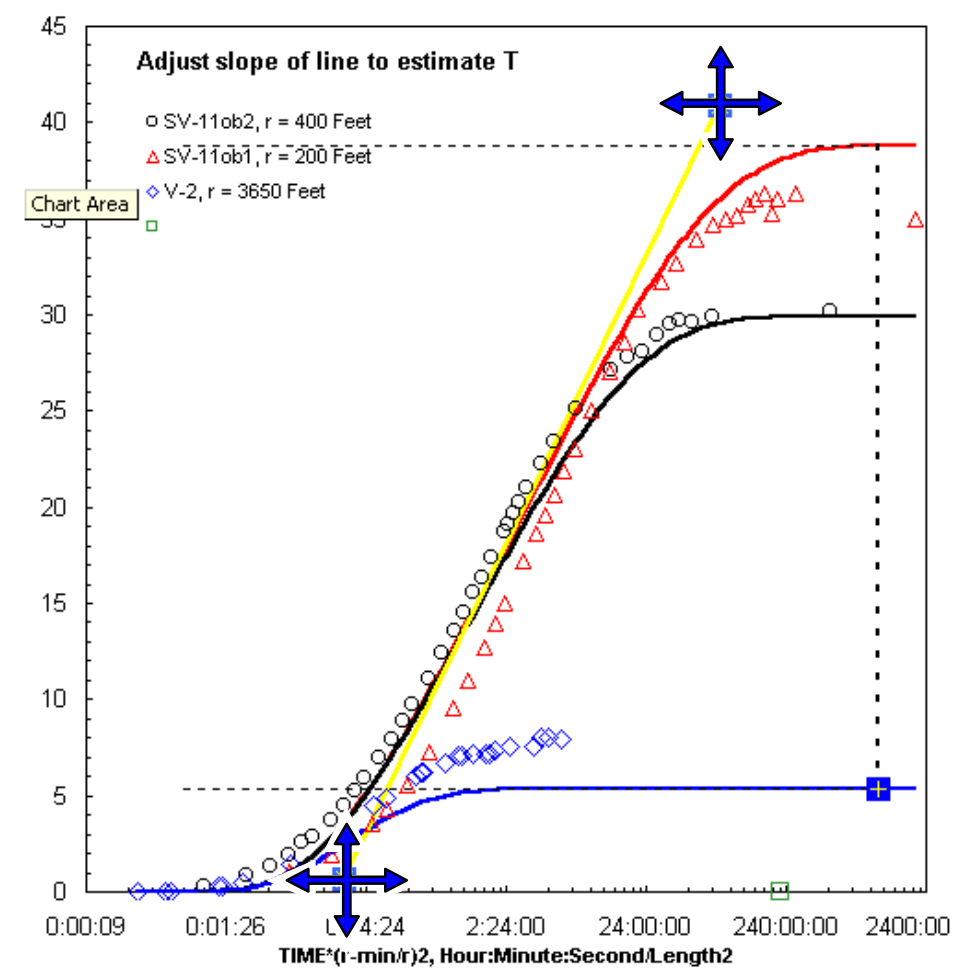

\section{GET CROSS}

A cross-arrow will appear with 2 clicks (not a double-click).

\section{SHIFT TO FIT}

The ends of the yellow line can be shifted along the $\mathrm{X}$-axis or $\mathrm{Y}$-axis until the slope of the line parallels and is centered on the measured data. 


\section{ESTIMATE $K_{\mathbf{Z}} / \mathbf{b}^{\prime}$}

Estimate vertical leakance by fitting the simulated drawdown plateaus to the measured drawdowns. Grab the marker on the most distant simulated drawdown and adjust it up and down along the Y-axis.

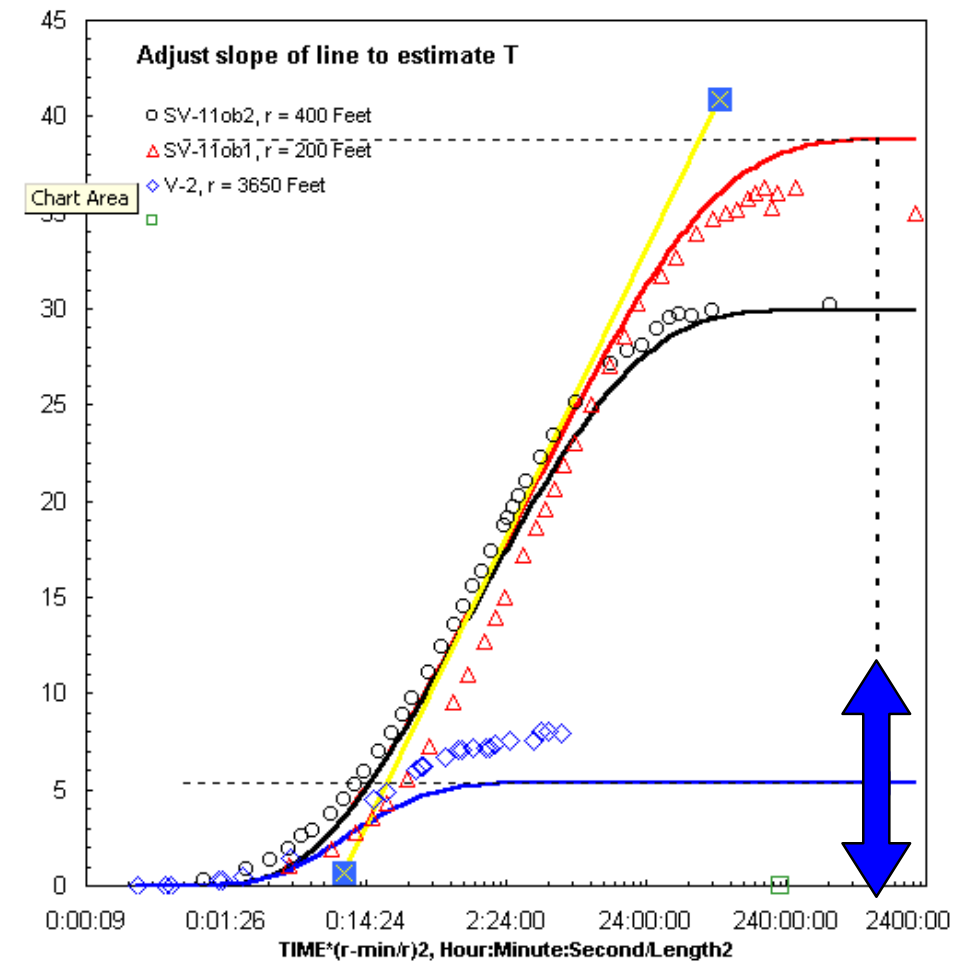




\section{SLUG-TEST SPREADSHEETS}

Slug tests are commonly used to obtain hydraulic property information at contaminant sites where it is desirable to minimize discharge of contaminated water. The slug test is fairly easy to perform. It consists of measuring the static water level (head) in the well, then introducing a near instantaneous change in water level, and measuring the change in water level over time until the water level returns to the original static water level. The instantaneous change in head can be achieved by adding or removing a volume of water or solid into the well. Originally, slug tests were developed for low permeability materials and were accomplished with bailers, a stopwatch, and a graduated steel tape. For very small diameter wells or in cases where it's desirable to minimize contact with contaminated ground water, the recovery data from air-pressurized tests can be analyzed.

A slug test provides a very local estimate of hydraulic conductivity or transmissivity in the near vicinity of a well. Slug tests are frequently performed prior to designing a multi-well aquifer test in order to site observation wells and determine feasible discharge rates. Slug tests are sometimes used to evaluate well development (fouling) and determine if an observation well is hydraulically connected to the aquifer.

The naming convention for slug tests can be confusing because the test may be accomplished by either an instantaneous rise or drop in water level. A test that is initiated with a sudden rise in water level is known as a slug test, slug-in test, or falling-head test. A test that involves a sudden drop in water level is referred to as a slug-out test, bailer test, or rising-head test (Butler, 1997).

Slug tests are frequently performed on higher hydraulic conductivity materials (1-100 ft/day) with the advent of more sensitive and accurate transducers and data loggers. These tests can recover within minutes. In higher hydraulic conductivity materials, it is advisable to repeat rising-head and falling-head tests 2 or 3 times with different volumes of slugs. If all of the estimated $\boldsymbol{K}$ values are similar, it would be fair to assume that the well is properly developed. A consistent difference between rising-head versus falling-head tests, indicates that the well screen may be fouled or air has been entrained between the borehole and casing above the well screen and well seal. The well is probably in need of development if all results are inconsistent.

Well construction and slug volume information are critical to the analysis of slug-test data. Both the effective screen length and effective radius of the well screen are required. The nominal screen length generally is used for effective screen length (Butler, 1997). For effective radius, either the nominal radius of the well screen or the radius of the filter pack generally is used. Butler (1997) suggests that the radius of the filter pack be used if the filter pack is more than twice as permeable as the formation. The volume of the slug is used to calculate the theoretical displacement. The theoretical displacement is checked with the actual displacement to test the validity of the effective radius of the well based on the following formula (Butler, 1997):

$$
r_{E C}=r_{C} \sqrt{\frac{y_{E}}{y_{O}}}
$$

where, $r_{E C}$ is effective casing radius $(L)$,

$r_{C}$ is the nominal casing radius $(L)$,

$y_{E}$ is the theoretical displacement estimated from the slug volume and casing diameter (L), and

$y_{0}$ is the observed displacement (L). 
As for pumping aquifer tests, several analytical methods have been developed for the analysis of slug tests. Spreadsheets were developed for the most commonly used methods; Bouwer and Rice (1976); Cooper and others (1967); and van der Kamp (1976). The Bouwer and Rice spreadsheet provides estimates of hydraulic conductivity from which transmissivity may be estimated. For partially penetrating wells, the contributing interval was assumed to be the length of the well screen because of the limited radius of investigation of a slug test. Transmissivity is estimated instead of hydraulic conductivity with the Cooper and others and van der Kamp spreadsheets. 
Instructions for Entering Data Into All of the Slug Test Spreadsheets

\section{PASTE DATA}

Paste time series data on the DATA sheet.

\section{ADJUST HEADINGS}

Adjust the headings to match the units of the time and water-level change columns.

Enter the site name, date, well construction, and aquifer properties in the INPUT section on the OUTPUT sheet.

\section{DESCRIBE SLUG}

Enter the information about the method used to create the displacement and remember to select the proper units.

\begin{tabular}{|c|c|c|c|c|}
\hline & $\mathrm{B}$ & C & D & \\
\hline 1 & & Number & f points $=$ & 100 \\
\hline 2 & & & & \\
\hline 3 & & \multicolumn{3}{|c|}{ INPUT } \\
\hline 4 & \multicolumn{2}{|c|}{ Slug Description: } & & \\
\hline 5 & & Type: & Bailer & \\
\hline 6 & & LENGTH & 4 & Feet \\
\hline 7 & & Rod Diameter & 2.5 & Inch \\
\hline 8 & \multicolumn{4}{|c|}{ Overwrite with your data here. } \\
\hline 9 & $\downarrow$ & $\downarrow$ & $\downarrow$ & $\downarrow$ \\
\hline 10 & Day & Empty & Second & Feet \\
\hline 11 & 227 & 1408 & 5.2 & 4.64 \\
\hline 12 & 227 & 1408 & 6.2 & 4.817 \\
\hline 13 & 227 & 1408 & 7.2 & 4.825 \\
\hline 14 & 227 & 1408 & 8.2 & 4.802 \\
\hline 15 & 227 & 1408 & 9.2 & 4.864 \\
\hline
\end{tabular}

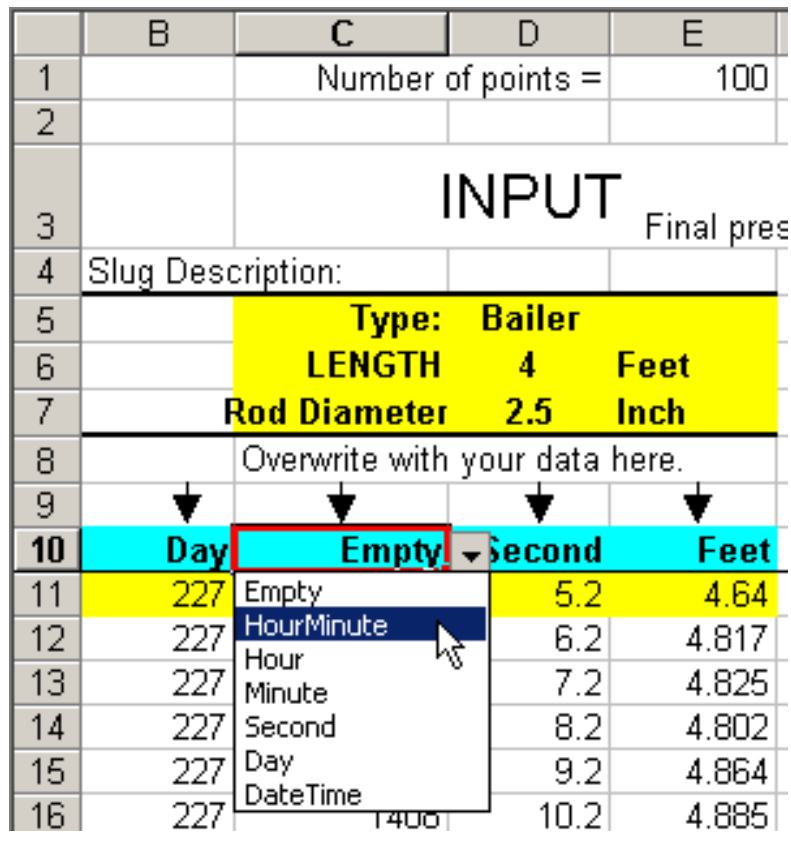

\begin{tabular}{|c|c|c|c|c|}
\hline \multicolumn{2}{|c|}{ Slug Description: } & & & \\
\hline & Type: & Bailer & & \\
\hline & LENGTH & $\begin{array}{l}\text { AIR } \\
\text { Briler }\end{array}$ & OF SLUGINC & \\
\hline & Rod Diameter & & the water & \\
\hline & Overwrite with & your disp & & \\
\hline$\downarrow$ & $\downarrow$ & & & \\
\hline Day & Hourhlinute & Second & Feet & $\mathrm{Hr}$ \\
\hline 227 & 1408 & 5.2 & 4.64 & \\
\hline 227 & 1408 & 6.2 & 4.817 & \\
\hline 227 & 1408 & 7.2 & 4.825 & \\
\hline
\end{tabular}




\section{Bouwer and Rice Method}

The Bouwer and Rice (1976) method is based on the Thiem (1906) analytical solution and was originally designed for the analysis of data from wells in unconfined aquifers. However, the method may be used to analyze data for confined aquifers. If the water-table is within the well screen only the rising head test should be analyzed for hydraulic conductivity. The Bouwer and Rice method estimates hydraulic conductivity of the aquifer near the screen.

The following assumptions apply:

- A volume of water is injected into, or is discharged from, the well instantaneously at $t=0$.

- Well is of finite diameter and may partially penetrate the aquifer. 
Instructions for Estimation of $\boldsymbol{K}$ from the Bouwer and Rice Spreadsheet

\section{SELECT}

Estimate hydraulic conductivity by grabbing the end of the red line

\section{GET CROSS}

A cross-arrow will appear with 2 clicks (not a double-click).

\section{SHIFT TO FIT}

The ends of the red line can be shifted along the $\mathrm{X}$-axis or $\mathrm{Y}$-axis until the slope of the line parallels the measured data.
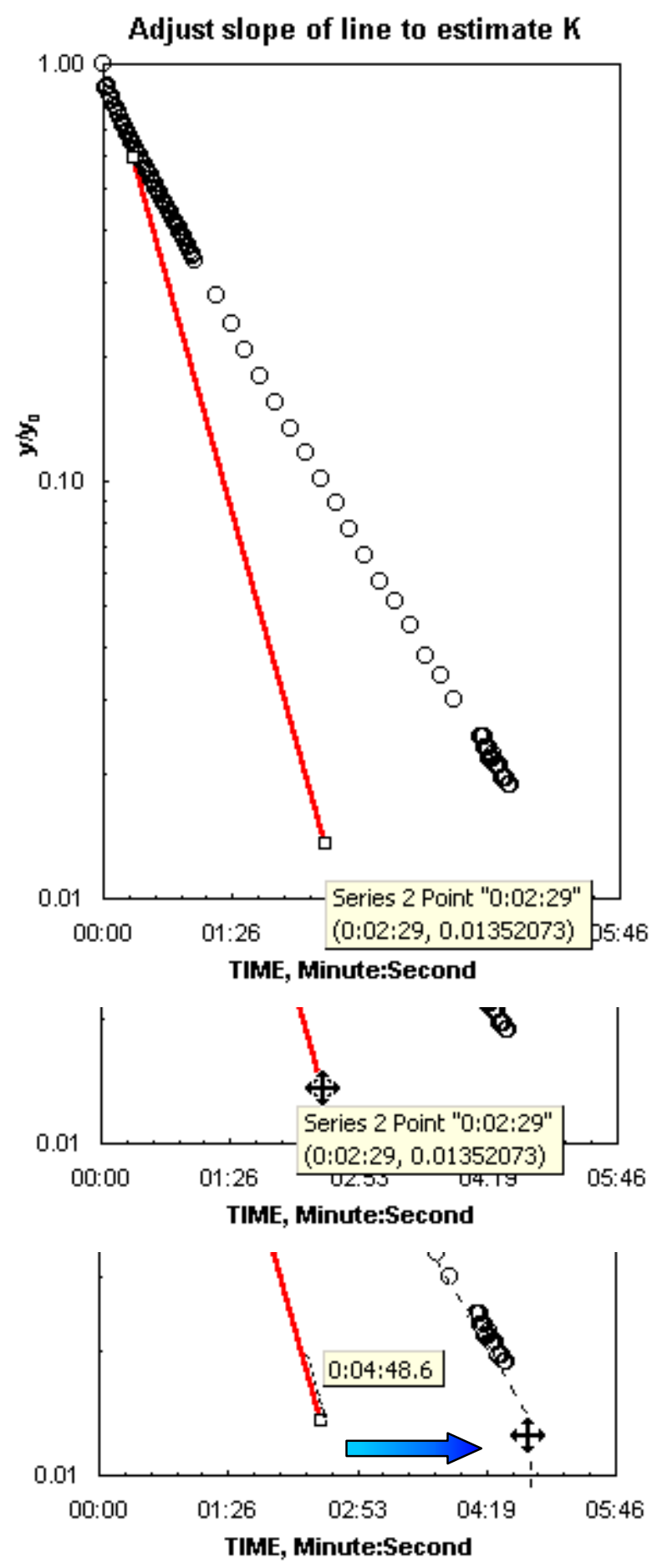


\section{van der Kamp Method}

The van der Kamp (1976) method was developed for the analysis of slug-test data from highly transmissive aquifers, as evidenced by oscillatory water-level response to a slug displacement. When slug tests are performed in high hydraulic conductivity materials or in wells with a very long water column above the screen or open interval, the water level response frequently oscillates rapidly. This is referred to as an underdamped response. The amplitude of the oscillation decreases with time, but the damping (slope of a line across the top of the peaks of the absolute value of the displacement data) remains constant, as does the frequency of the oscillations. This information is used to estimate transmissivity. A sensitive transducer and data logger capable of recording data at intervals of 0.2 seconds or less are needed for data collection. Van der Kamp (1976) developed the following equations for estimating transmissivity from the frequency of the oscillation and the damping coefficient:

$$
T=b+2.3 a \log _{10}(T)
$$

where,

$$
\begin{aligned}
& a=\frac{\left(\gamma^{2}+\omega^{2}\right) r_{c}^{2}}{8 \gamma} \\
& b=-2.3 a \log _{10}\left(0.79 r_{W}^{2} S \sqrt{\gamma^{2}+\omega^{2}}\right)
\end{aligned}
$$

where, $\boldsymbol{T}$ is transmissivity $\left(\mathrm{L}^{2} / \mathrm{T}\right)$,

$\gamma$ is the damping coefficient (1/T),

$\omega$ is the frequency of the oscillation (1/T),

$r_{c}$ is the casing radius $(L)$, and

$r_{w}$ is the wellbore radius (L).

The van der Kamp method assumes that the aquifer is homogeneous, the well is fully penetrating, and $\omega$ and $\gamma$ remain constant. A storage coefficient must be assumed to use the van der Kamp spreadsheet. 


\section{Instructions for Estimation of $\boldsymbol{T}$ from the van der Kamp Spreadsheet}

Damping coefficient $(\gamma)$ and frequency $(\omega)$ are estimated from measured aquifer responses to estimate $\boldsymbol{T}$. Measured $(\mathrm{O})$ and simulated $(-)$ aquifer responses are depicted in two charts as absolute-displacement from the initial water level and displacement from the initial water level (See below). Both charts are on the OUTPUT sheet.
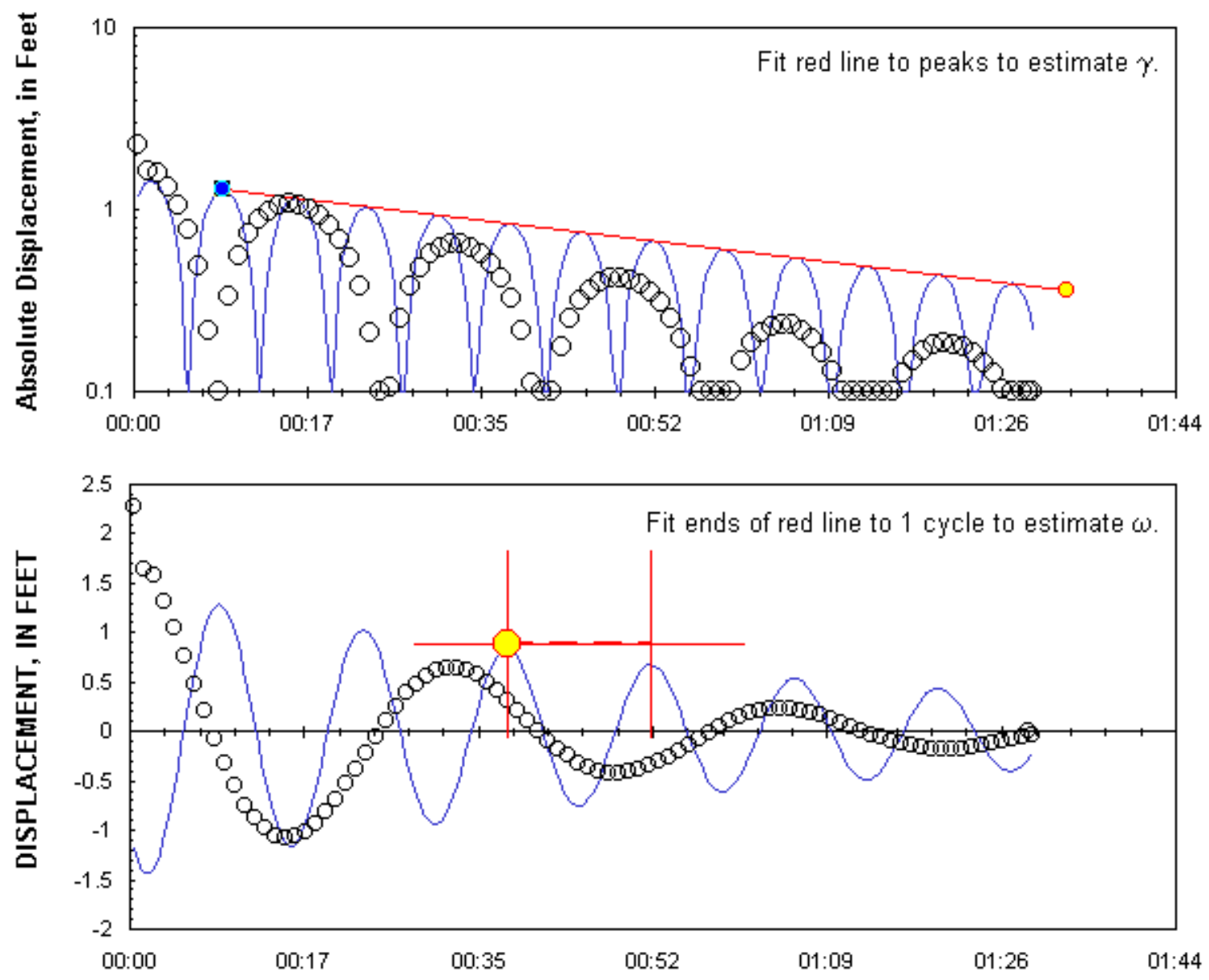

\section{SELECT}

Estimate the damping coefficient $(\gamma)$ by grabbing the end of the red line

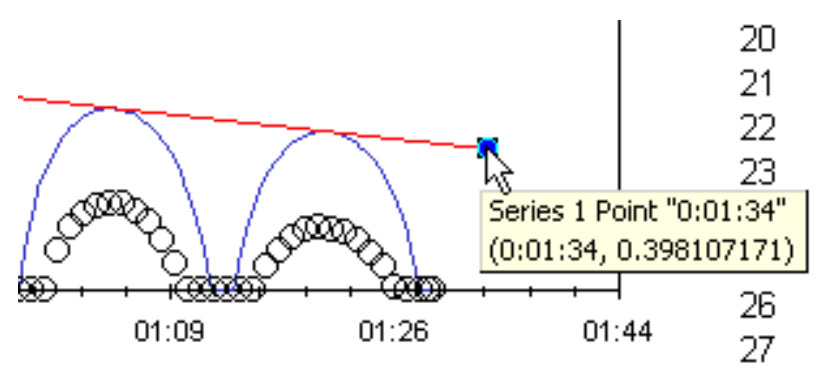




\section{GET CROSS}

A cross-arrow will appear with 2 clicks (not a double-click).

\section{SHIFT TO FIT}

The ends of the red line can be shifted along the $\mathrm{X}$-axis or $\mathrm{Y}$-axis until the red line intercepts the peaks of the measured data.
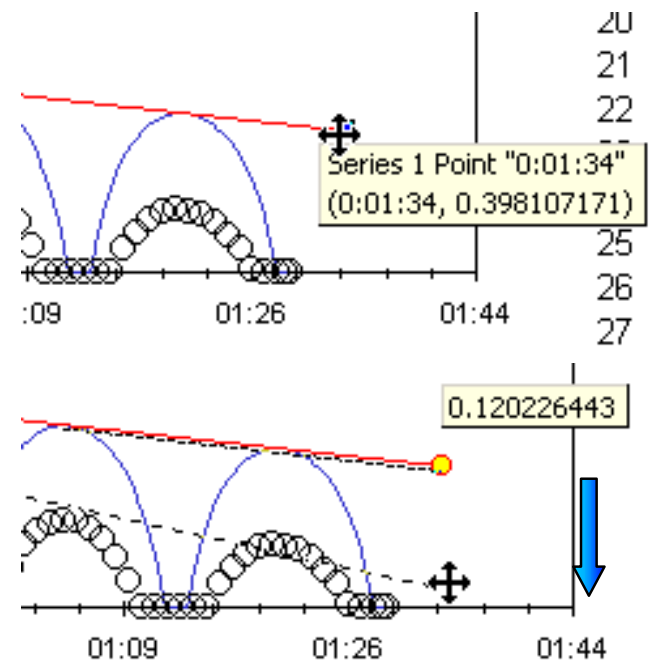
Frequency $(\omega)$ is estimated by fitting the red crosses in the displacement chart to the measured peaks. The vertical position of the 2 crosses does not affect estimates of $\boldsymbol{T}$, but can be adjusted for convenience by moving the right cross without a yellow ball.
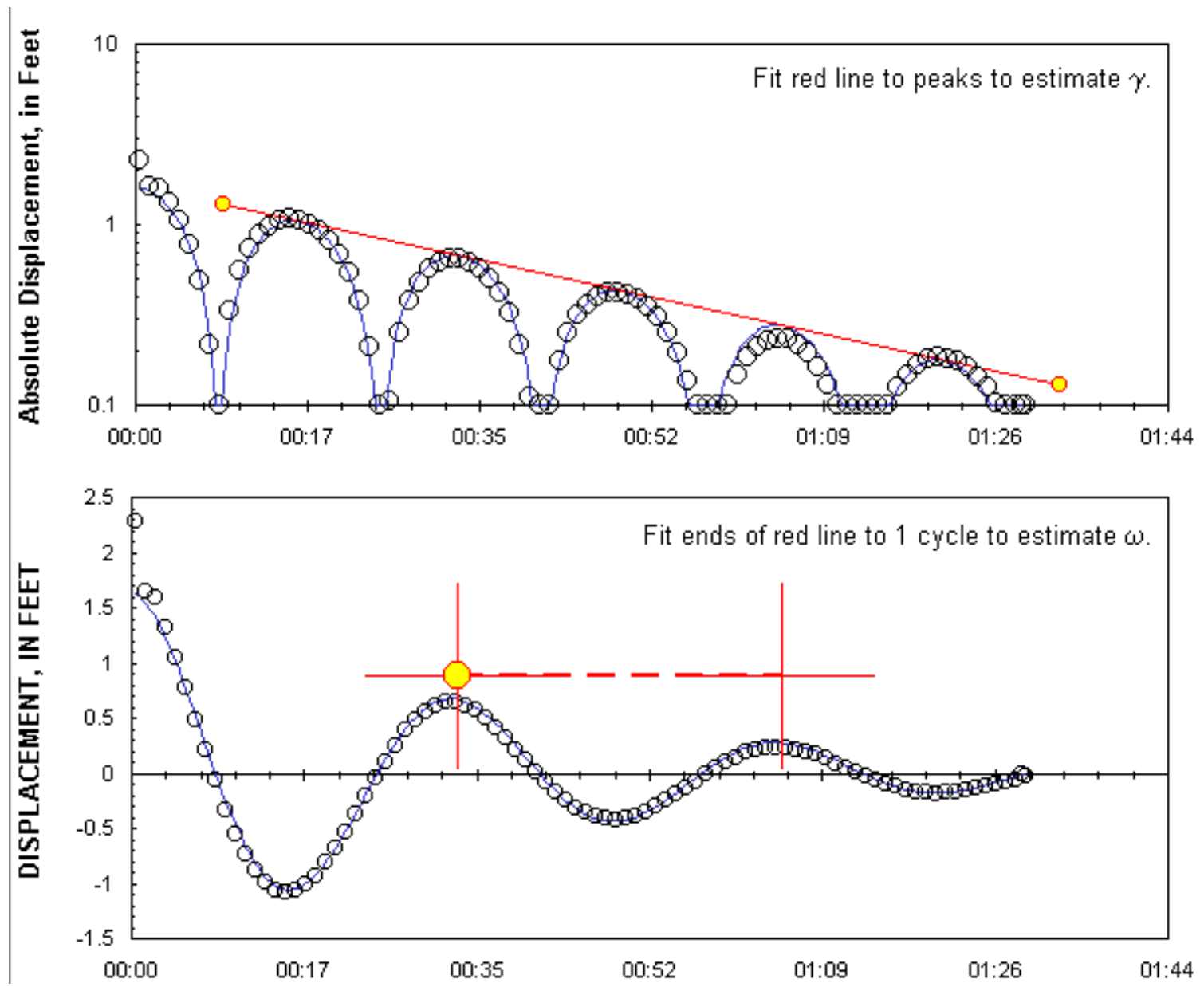


\section{Cooper, Bredehoeft, and Papadopulos Method as Modified by Greene and Shapiro}

The Cooper, Bredehoeft, and Papadopulos (1967) method was originally developed for the analysis of ordinary slug tests. Greene and Shapiro (1995) extended the method for the analysis of very low permeability material where the introduced slug does not reach equilibrium before being removed. The original assumptions were:

- A volume of water is instantaneously injected or withdrawn from the well at the beginning of the test, $\boldsymbol{t}=0$.

- The well is of finite diameter and fully penetrates the aquifer.

- The aquifer is confined and flow is strictly radial.

Storage is not estimated reliably with this method because changes in storage do not appreciably affect the shape of the simulated response. Transmissivity estimates are affected minimally by the value of storage that is assigned. Greene and Shapiro (1995) state

“* * * Air-pressurized slug tests offer a means of estimating formation transmissivity and storativity without extensive downhole equipment and in situations where contact with formation fluids may pose a health concern. An air-pressurized slug test, as discussed in this paper, consists of applying a constant pressure to the column of air in a well, monitoring the declining water level, and then releasing the air pressure and monitoring the recovering water level. If the maximum declining (or new equilibrium) water level is achieved for a constant applied air pressure, the slug-test solution of Cooper et al. (1967) can be used to interpret the water-level recovery data and estimate the formation properties. In lowpermeability terrains, the time required to achieve the equilibrium water level during the pressurized part of the test may be too long for practical purposes, and it may be necessary to terminate the applied air pressure prior to establishing a new equilibrium. To analyze data from such tests, a solution to the boundary-value problem for the declining and recovering water level during an air-pressurized slug test is developed for an arbitrary time-dependent air pressure applied to the well. For the special case of applying a constant air pressure and then reducing it instantaneously to atmospheric pressure at a prescribed time, the general solution reduces to the superposition of the solution of Cooper et al. (1967) at two displaced times. Type curves are generated to estimate formation transmissivity and storativity from the recovering water level associated with prematurely terminated air-pressurized slug tests. 
Instructions for Estimation of $\boldsymbol{T}$ and $\boldsymbol{S}$ from the Cooper and others Spreadsheet

\section{GET CROSS}

Estimate transmissivity and storage by adjusting the blue and yellow match point. Displacement along the $X$-axis changes $T$ while shifts along the $\mathrm{Y}$-axis changes $\boldsymbol{S}$.

A cross-arrow will appear with 2 clicks (not a double-click) on the match point.

\section{SHIFT MATCH POINT}

Estimate displacement needed to fit the red line to the measured values.

\section{RELEASE}

The red curve will shift and the $\boldsymbol{T}$ estimate will be updated after the match point is released.
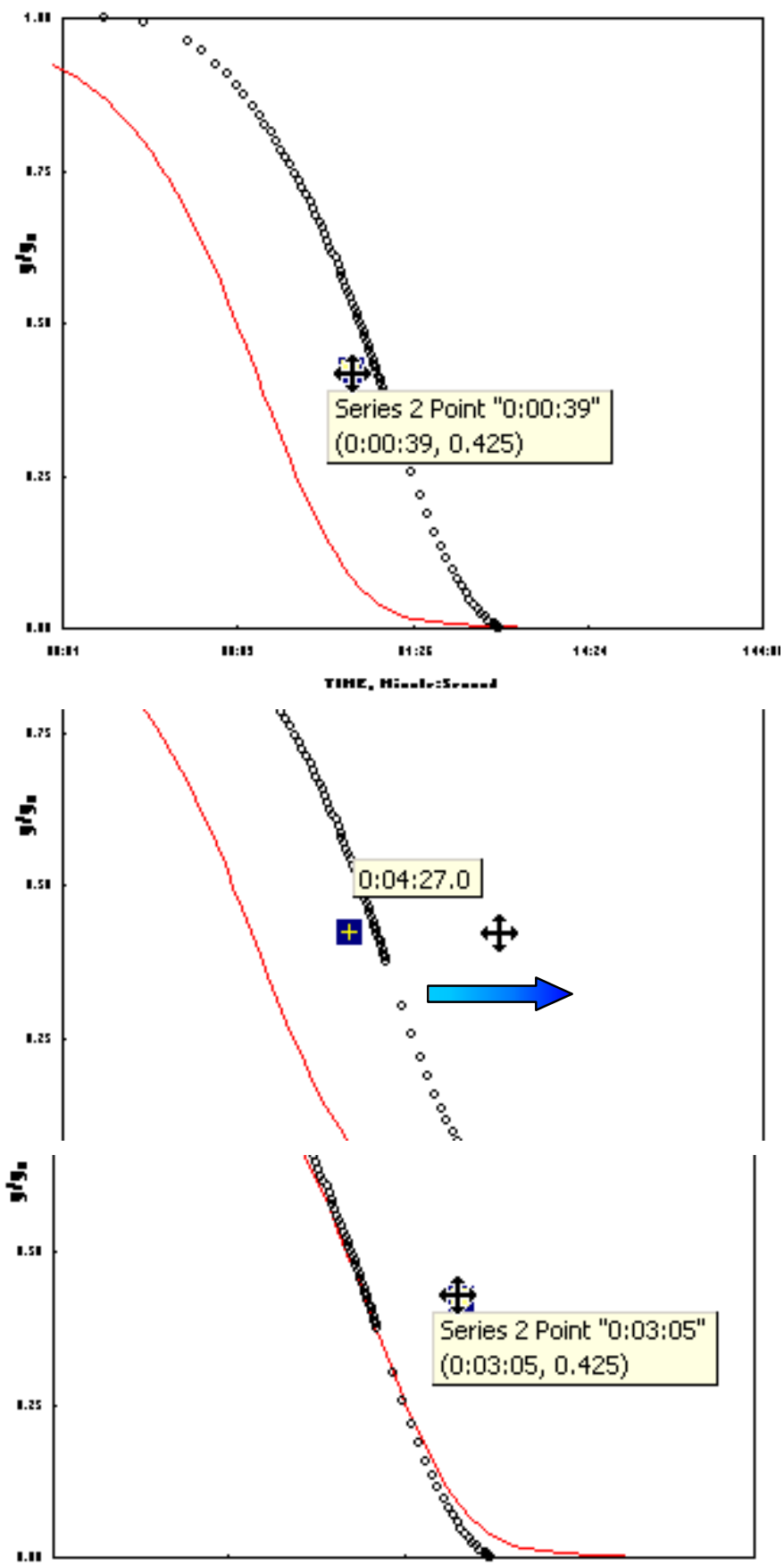


\section{REFERENCES}

Aucott, W.R. and Newcome, Roy, Jr., 1986, Selected aquifer-test information for the coastal plain aquifers of South Carolina: U.S. Geological Survey Water-Resources Investigations Report 86-4159, 30 p.

Barlow, P.M. and Moench, A.F., 1999, WTAQ-Acomputer program for calculating drawdowns and estimating hydraulic properties for confined and water-table aquifers: U.S. Geological Survey Water-Resources Investigations Report 994225, $74 \mathrm{p}$.

Benthall, Ray, 1963, Methods of determining permeability, transmissibility, and drawdown: U.S. Geological Water-Supply Paper 1536-I, $100 \mathrm{p}$

Bouwer, Herman, 1978, Groundwater Hydrology: McGraw-Hill, New York, 480 p.

Bouwer, Herman and Rice, R.C., 1976, A slug test for determining hydraulic conductivity of unconfined aquifers with completely or partially penetrating wells, Water Resources Research 12(3) 423-428.

Butler, J.J., Jr., 1997, The design, performance, and analysis of slug tests: Lewis Publishers, Washington, D.C., 252 p.

Cooper, H.H. and Jacob, C.E., 1946, A generalized graphical method for evaluating formation constants and summarizing well field history, American Geophysical Union Transactions, v. 27, 526-534.

Cooper, H.H., Jr., Bredehoeft, J.D., and Papadopulos, I.S., 1967, Response of a finite-diameter well to an instantaneous charge of water. Water Resources Research v. 3, 263-269.

Davis, S.D., 1969, Porosity and permeability of natural materials, in Flow Through Porous Media, edited by De Wiest, R.J.M.: Academic Press, New York, 53-89.

Dawson, Karen and Istok, Jonathan, 1991, Aquifer Testing: Design and Analysis of Pumping and Slug Tests: Lewis Publishers, $280 \mathrm{p}$.

Domenico, P.A. and Schwartz, F.W., 1990, Physical and Chemical Hydrogeology: New York, John Wiley and Sons, 824 p.

Driscoll, F.G., 1986, Groundwater and wells, second edition: Johnson Division, St Paul, Minnesota, 1089 p.

Earlougher, R.C., Jr., 1977, Advances in well test analysis, Sociecty of Petroleum Engineers of AIME, Dallas, Texas, 264 p.

Ferris, J.G., Knowles, D.B., Brown, R.H., and Stallman, R.W., 1962, Theory of aquifer tests: U.S. Geological Water-Supply Paper 1536-E, $174 \mathrm{p}$.

Fetter, C.W., 1994, Applied Hydrogeology, Third Edition: Macmillan, NY, 691 p.

Greene, E.A. and Shapiro, A.M., 1995, Methods of conducting air-pressurized slug tests and computation of type curves for estimating transmissivity and storativity: U.S. Geological Survey Open-File Report 95-424.

Greene, E.A. and Shapiro, A.M., 1998, AIRSLUG: A FORTRAN program for the computation of type curves to estimate transmissivity and storativity of prematurely terminated air-pressurized slug tests. Ground Water. v. 36(2), 373-376 p.

Hantush, M.S. and Jacob, C.E., 1955, Non-steady flow in an infinite leaky aquifer: Transactions of the American Geophysical Union, vl. 36, 95-100.

Hall, Phil and Chen, Joe, 1996, Water Well and Aquifer Test Analysis: Water Resources Publication, 412 p.

Hovorka, S.D., Mace, R.E., and Collins, E.W., 1995, Regional distribution of permeability in the Edwards Aquifer: Edwards Underground Water District Report 95-02, 128 p.

Jacob, C.E., 1947, Drawdown test to determine the effective radius of artesian well: Transaction of the American Society of Civil Engineers, Paper 2321, v. 112, 1047-1064 p. 
Jacob, C.E. and Lohman,S.W., 1952, Nonsteady flow to a well of constant drawdown in an extensive aquifer: Transaction of the American Geophysical Union, v. 33(4), 559-569 p.

Johnson, A.I., 1967, Specific yield-compilation of specific yields for various materials: U.S. Geological Survey Water-Supply Paper 1662-D.

Kasenow, Michael, 1997, Introduction to Aquifer Analysis: Water Resources Publication, LLC, 413 p.

Kawecki, M.W., 1995, Meaningful interpretation of step-drawdown tests: Ground Water, v. 33(1), 23-32 p.

Kruseman, G.P. and de Ridder, N.A., 1994, Analysis and Evaluation of Pumping Test Data: International Institute for Land Reclamation and Improvement, The Netherlands, 377 p.

Kuniansky, E.L. and Hamrick, S.T., 1998, Hydrogeology and simulation of ground-water flow in the Paluxy aquifer in the vicinity of landfills 1 and 3, U.S. Air Force Plant 4, Fort Worth, Texas: U.S. Geological Survey Water-Resources Investigations Report 98-4023, $34 \mathrm{p}$.

Lee, John, 1982, Well Testing: Society of Petroleum Engineers of AIME: New York, 159 p.

Lohman, S.W., 1979, Ground-Water Hydraulics: U.S. Geological Survey Professional Paper 708, 70 p.

Maclay, R.W. and Small,T.A., 1986, Carbonate geology and hydrology of the Edwards aquifer in the San Antonio area, Texas: Texas Water Development Board Report 296, 90 p.

Marie, J.R. and Hollet, K.J., 1996, Determination of hydraulic characteristics and yield of aquifers underlying Vekol Valley, Arizona, using several classical and current methods: U.S. Geological Survey Water-Supply Paper 2453, 63 p.

Maslia, M.L. and Randolph, R.B., 1986, Methods and computer program documentation for determining anisotropic transmissivity tensor components of two-dimensional ground-water flow: U.S. Geological Survey Open-File Report 86-227, $64 \mathrm{p}$.

Miller, J.A., 1990, Ground water atlas of the United States Segment 6, Alabama, Florida, Georgia, and South Carolina: U. S. Geological Survey Hydrologic Investigations Atlas 730-G, 28 p.

Morris, D.A. and Johnson, A.I., 1967, Summary of hydrologic and physical properties of rock and soil material as analyzed by the Hydrologic Laboratory of the U.S Geological Survey 1948-60: U.S. Geological Survey Water-Supply Paper 1839$\mathrm{D}, 42 \mathrm{p}$.

Neuzil, C.E., 1994, How permeable are clays and shales?: WRR, 30, 2, p. 145-150.

Newcome, Roy, Jr., 1993, Pumping tests of the coastal plain aquifers in South Carolina: State of South Carolina Water Resources Commission Report 174, 52 p.

Prince, K.R. and Hollett, K.J., 2002, Documentation of data from aquifer-tests conducted in Vekol Valley, Arizona, December 1979 to January 1984: U.S. Geological Survey Open-File Report 02-XXX, in press

Prudic, D.E., 1991, Estimates of hydraulic conductivity from aquifer-test data and specific-capacity data, Gulf Coast Regional Aquifer Systems, south-central United States: U.S. Geological Survey Water-Resources Investigations Report 90$4121,38 \mathrm{p}$.

Reed, J.E., 1980, Type curves for selected problems of flow to wells in confined aquifers: U.S. Geological Survey Techniques of Water-Resources Investigations, book 3, chap. B3, 106 p.

Reese, R.S. and Cunningham, K.J., 2000, Hydrogeology of the Gray Limestone Aquifer in southern Florida: U.S. Geological Survey Water-Resources Investigations Report 99-4213, 244 p. 
Rorabaugh, M.I., 1953, Graphical and theoretical analysis of step-drawdown test of artesian well: Proceedings, American Society of Civil Engineers, v. 79.

Sepulveda, Nicasio, 1992, Computer algorithm for the analysis of underdamped and overdamped water-level responses in slug tests: U.S. Geological Survey Water-Resources Investigations Report 91-4162, 20 p.

Slack, L.J. and Darden, Daphne, 1991, Summary of aquifer tests in Mississippi, June 1942 through May 1988: U.S. Geological Survey Water-Resources Investigations Report 90-4155, 40 p.

Smith, L.P., 1937, Heat flow in an infinite solid bounded internally by a cylinder: Journal of Applied Physics, v. 8, 441-448 p.

Stallman, R.W., 1971, Aquifer-test design, observation, and data analysis: U.S. Geological Survey Techniques of WaterResources Investigations, book 3, chap. B1, 26 .

Thiem, G., 1906, Hydrologische Methodern: Leipzig, Geghardt, 56 p.

Theis, C.V., 1935, The relation between the lowering of the piezometric surface and the rate and duration of discharge of a well using ground water storage: Transaction of American Geophysical Union, v. 16, 519-524 p.

Theis, C.V., 1938, The significance and nature of the cone of depression in ground-water bodies: Economic Geology, v. 38, 889-902 p.

van der Kamp, Garth, 1976, Determining aquifer transmissivity by means of well response tests: the underdamped case: Water Resources Research, v. 12(1), 71-77 p.

Vukovic, Milan and Soro, Andjelko, 1992, Determination of hydraulic conductivity of porous media from grain-size composition: Water Resources Publications, Littleton, Colorado, 83 p.

Walton, William, 1996, Aquifer Test Analysis with Windows ${ }^{\mathrm{TM}}$ : CRC Press, Boca Raton, Florida, $336 \mathrm{p}$.

Weissman, Warren, Jr., Knapp, J.W., Lewis, G.L., and Harbaugh, T.E., 1977, Introduction to Hydrology: Harper and Row, NY, $704 \mathrm{p}$.

Whitehead, R.L., 1994, Ground water atlas of the United States Segment 7, Idaho, Oregon, and Washington: U. S. Geological Survey Hydrologic Investigations Atlas 730-H, 31 p.

Wolff, R.G., 1982, Physical properties of rocks—Porosity, permeability, distribution coefficients, and dispersivity: U.S. Geological Survey Open-File Report 82-166, 118 p. 